\title{
Integrated Municipal Solid Waste Management: Six Case Studies of System Cost and Energy Use
}

\section{A Summary Report}

National Renewable Energy Laboratory 1617 Cole Boulevard Golden, Colorado 80401

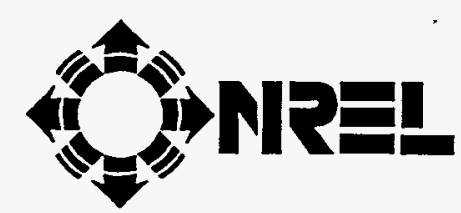

National Renewable Energy Laboratory 1617 Cole Boulevard Golden, Colorado 80401-3393 A national laboratory of the U.S. Department of Energy Managed by the Midwest Research Institute for the U.S. Department of Energy

Under Contract No. DE-AC36-83CH10093 



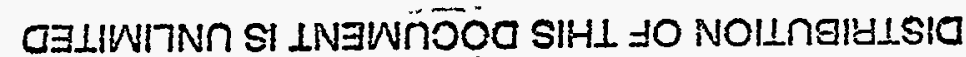

S66I دәquәムON

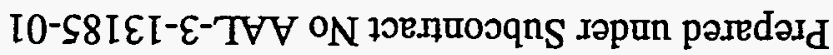

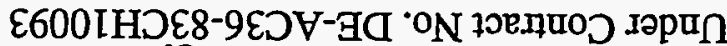

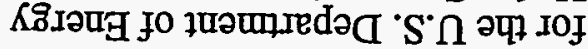

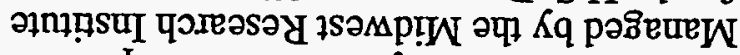

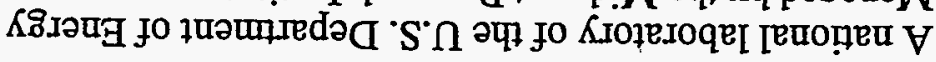

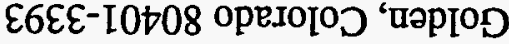
presə[nog ә[о L L9I

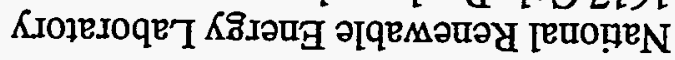

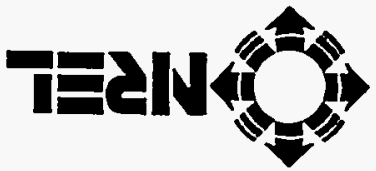

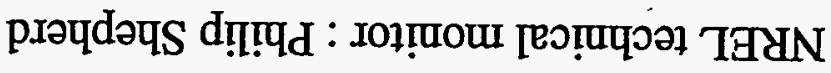

\section{ᄀ.Jodəy K.IBuuns V}

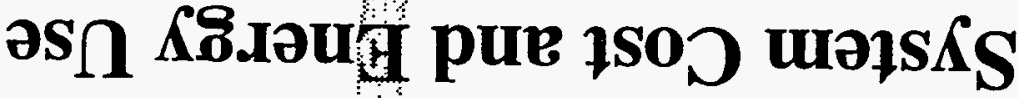

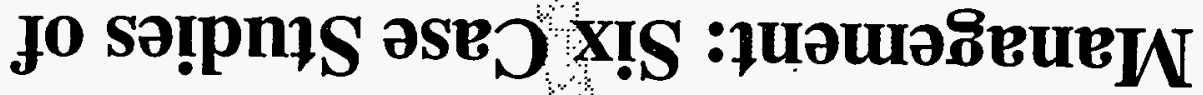

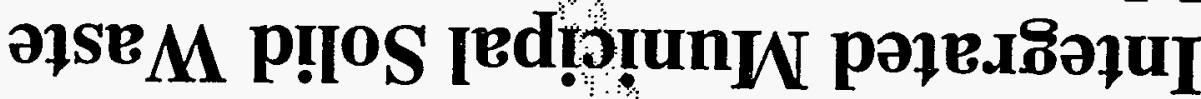




\section{NOTICE}

This report was prepared as an account of work sponsored by an agency of the United States government. Neither the United States government nor any agency thereof, nor any of their employees, makes any warranty, express or implied, or assumes any legal liability or responsibility for the accuracy, completeness, or usefulness of any information, apparatus, product, or process disclosed, or represents that its use would not infringe privately owned rights. Reference herein to any specific commercial product, process, or service by trade name, trademark, manufacturer, or otherwise does not necessarily constitute or imply its endorsement, recommendation, or favoring by the United States government or any agency thereof. The views and opinions of authors expressed herein do not necessarily state or reflect those of the United States government or any agency thereof.

Available to DOE and DOE contractors from:

Office of Scientific and Technical Information (OSTI)

P.O. Box 62

Oak Ridge, TN 37831

Prices available by calling (615) 576-8401

Available to the public from:

National Technical Information Service (NTIS)

U.S. Department of Commerce

5285 Port Royal Road

Springfield, VA 22161

(703) $487-4650$

Printed on paper containing at least $50 \%$ wastepaper, including $10 \%$ postconsumer waste

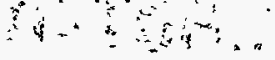




\section{Acknowledgements}

These case studies were jointly sponsored by the American Plastics Council and the National Renewable Energy Laboratory for the U.S. Department of Energy. The work was managed by the Solid Waste Association of North America.

The case studies could not have been accomplished without the support and assistance of the managers and staff at each system, as well as many other private service providers who contributed data to the project. In addition, many individuals served as technical advisors to the work, reviewing and commenting on each draft case study as it was produced. Those advisors, listed below, participated in one or more project review meetings, and in selecting case study sites, guiding the conduct of the case studies, questioning and correcting assumptions, and in determining the format of the final product. These advisors participated as individuals, not as official representatives of their organizations or institutions. We are grateful for their assistance and their insights.

Advisors: Robert Andrews, Dow Plastics; Paul Casowitz, Sive, Paget and Reisel; Marian R. Chertow, Yale University; Kenneth Chilton, Center for the Study of American Business; Steve Cramer, City of Minneapolis; William Ehrmann, York County (PA) Solid Waste Authority; Tom Houska, Delaware Solid Waste Authority; Daniel J. Kemna, WMX Technologies; Susan Moore, American Plastics Council; Sharon Oxley, Keep America Beautiful, Glass Packaging Institute; Ron Perkins, American Plastics Council; Jerry Powell, Resource Recycling Magazine; Jim Plumb, Aluminum Association; Lynn Scarlett, Reason Foundation; Sigurd Scheurle, Minnesota Office of Environmental Assistance; Kurt Sisson, U. S. Department of Energy; Philip Shepherd, National Renewable Energy Laboratory; Drew Sones, City of Los Angeles; Deb Starkey, National Conference of State Legislatures; Norman Steisel, former First Deputy Mayor, City of New York; Richard Storat, American Forest and Paper Association; N. C. Vasuki, Delaware Solid Waste Authority; Carlton Wiles, National Renewable Energy Laboratory; Iraj Zandi, University of Pennsylvania; Keith Zook, Procter and Gamble Company.

All the reports are available through the National Renewable Energy Laboratory, 1617 Cole Boulevard, Golden, Colorado, 80401; or call (303) 275-4363. The six reports are for the following integrated municipal solid waste systems:

- $\quad$ Minneapolis (Hennepin County), Minnesota; NREL/TP430-20473

- $\quad$ Palm Beach County, Florida; NREL/TP430-8131

- $\quad$ Scottsdale Arizona; NREL/TP430-7977

- $\quad$ Seattle, Washington; NREL/TP430-8129

- Sevierville, Tennessee; NREL/TP430-8136

- $\quad$ Springfield, Massachusetts; NREL/TP430-8137 


\section{Contents}

Page

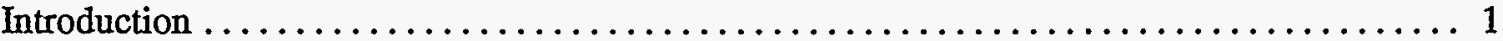

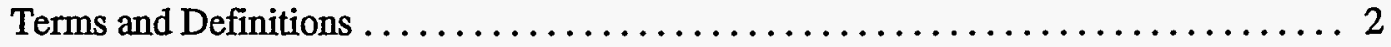

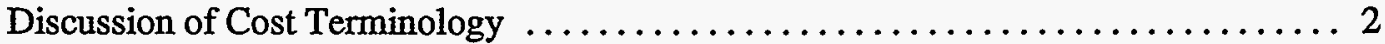

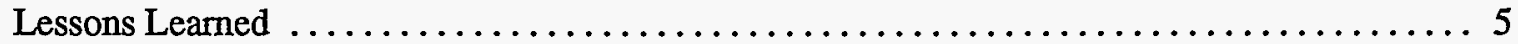

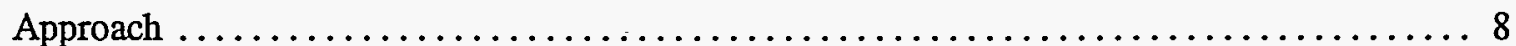

Gross, Net and Incremental Cost Methodology .................... 8

Define and Quantify "Analyzed MSW" .................... 12

Identify Total IMSWM System Gross and Net Costs ............. 12

Adjust Total IMSWM System Gross and Net Costs $\ldots \ldots \ldots \ldots \ldots \ldots \ldots 12$

Determine Applicable Costs/Revenues ................... 13

Allocation of Adjusted and Applicable Gross and Net Costs to

IMSWM System's Functional Areas . . . . . . . . . . . . . . . 13

Allocation of Adjusted and Applicable Costs/Revenues by Solid

Waste Type .................................... 14

Program Incremental Costs (Savings) $\ldots \ldots \ldots \ldots \ldots \ldots \ldots \ldots \ldots \ldots \ldots$

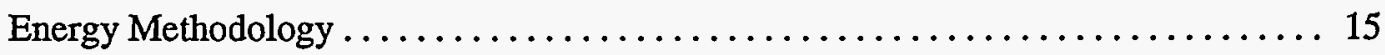

Types of Energy Included and Excluded from Analysis . . . . . . . . . 15

Calculation of System Component Energy Usage . . . . . . . . . . . . 15

Calculation of Energy Usage for Hauling . . . . . . . . . . . . . 16

Calculation of Energy Usage/Production for WTE Facilities .......... 16

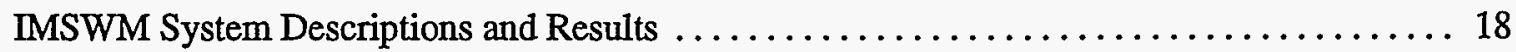

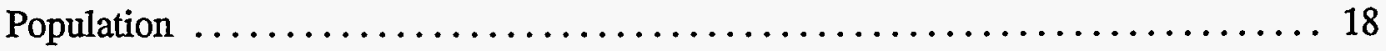

Economies, Institutional Arrangements, System Components, and Results ....... 18

City of Minneapolis (Hennepin County), Minnesota .................... 19

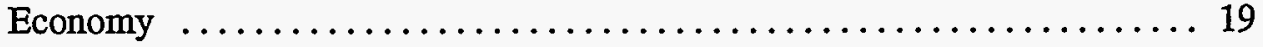

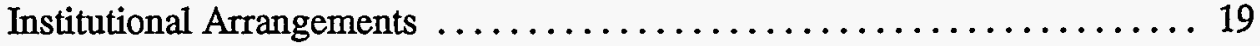

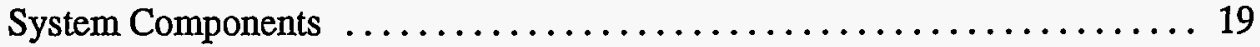

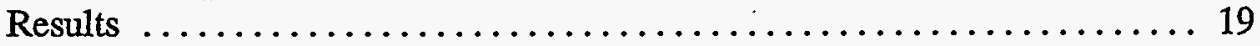

Palm Beach County (Solid Waste Authority of Palm Beach County, Florida . . . . . . 24

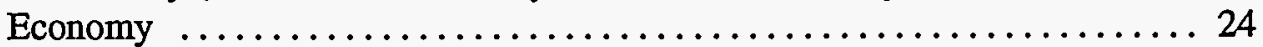

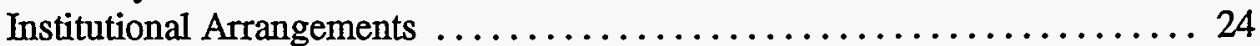

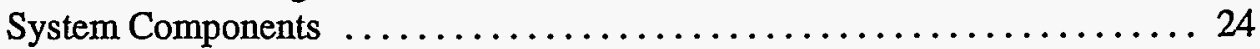

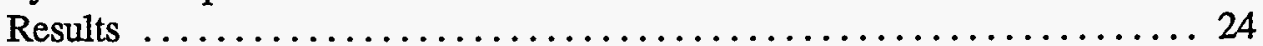




\section{Contents (Continued)}

Page

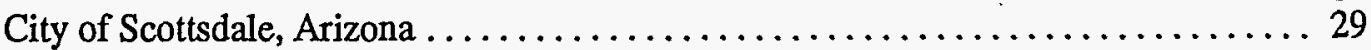

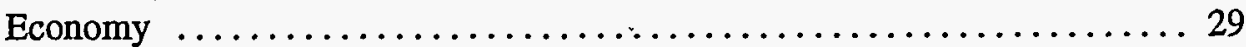

Institutional Arrangements ............................. 29

System Components ............................... 29

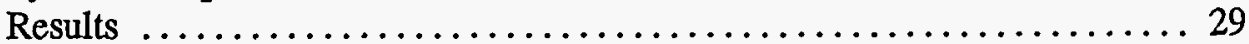

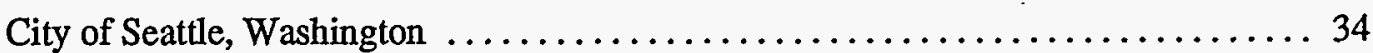

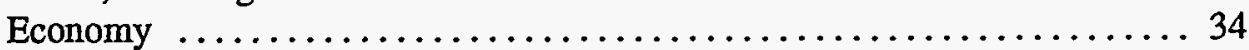

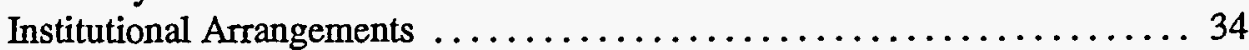

System Components .................................. 34

Results .......................................... 34

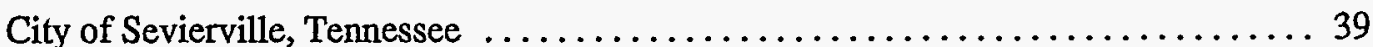

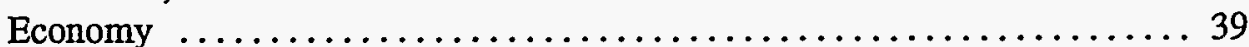

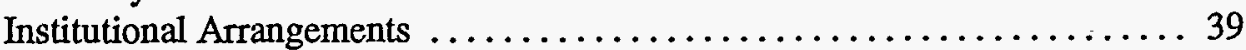

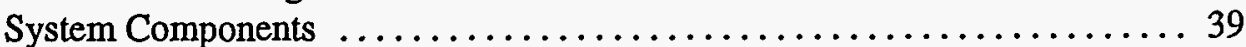

Results .......................................... 39

City of Springfield, Massachusetts ......................... 44

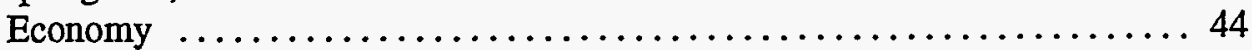

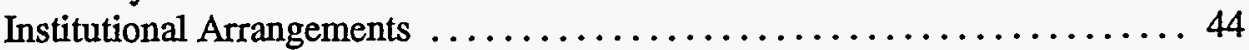

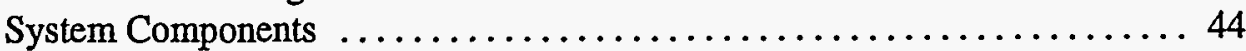

Results ....................................... 44 


\section{List of Figures}

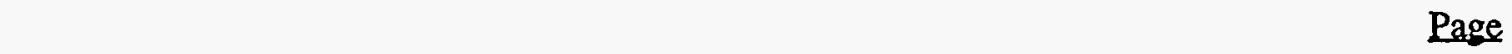

Figure 1: Total and Average Costs Before Adding a New Program $\ldots \ldots \ldots \ldots \ldots \ldots \ldots 3$

Figure 2: Total and Average Costs of MSW and Yard Waste Programs . . . . . . . . 3

Figure 3: Total, Average, and Incremental Costs of MSW and Yard Waste Programs ..... 3

Figure 4: Incremental Costs and Diversion for Selected Programs, as a Percentage

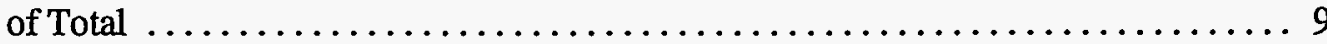

Figure 5: Cost Methodology for Determining Total and Net Costs for Allocating

Total Costs by Functional Area and Waste Type .................. 11

Figure 6: City of Minneapolis (Hennepin County) Total Waste (Tons) $\ldots \ldots \ldots \ldots \ldots \ldots$

Figure 7: City of Minneapolis (Hennepin County) Analyzed Waste by Type of

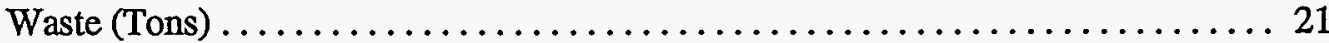

Figure 8: City of Minneapolis (Hennepin County) Net Costs of Managing

Analyzed MSW by Functional Area (FY 1992\$) .................. 22

Figure 9: City of Minneapolis (Hennepin County) Allocation of Net Costs by

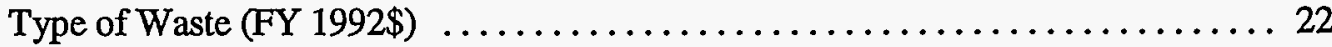

Figure 10: City of Minneapolis (Hennepin County) Functional Allocation of Net

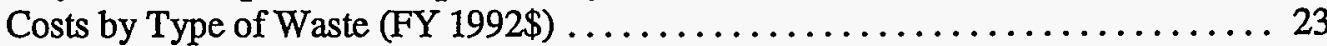

Figure 11: Palm Beach County Total Waste (Tons) $\ldots \ldots \ldots \ldots \ldots \ldots \ldots \ldots \ldots \ldots$

Figure 12: Palm Beach County Analyzed Waste by Type of Waste (Tons) $\ldots \ldots \ldots \ldots \ldots 26$

Figure 13: Palm Beach County Gross Costs of Managing Analyzed MSW by

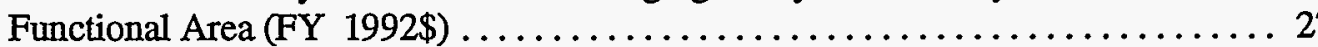

Figure 14: Palm Beach County Allocation of Total Net Costs by Type of Waste

(FY 1992\$)

Figure 15: Palm Beach County Functional Allocation of Gross Costs for Garbage/Trash

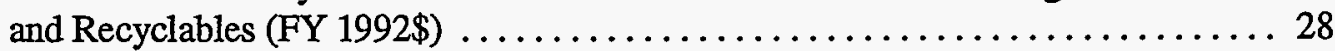

Figure 16: City of Scottsdale Total Waste (Tons) $\ldots \ldots \ldots \ldots \ldots \ldots \ldots \ldots \ldots \ldots \ldots$

Figure 17: City of Scottsdale Analyzed Waste by Type of Waste (Tons) $\ldots \ldots \ldots \ldots \ldots$ 


\section{List of Figures (Continued)}

Figure 18: City of Scottsdale Net Costs of Managing Analyzed MSW by Functional

Figure 19: City of Scottsdale Allocation of Net Costs by Type of Waste

(FY 1992\$)

Figure 20: City of Scottsdale Functional Allocation of Net Costs by Type

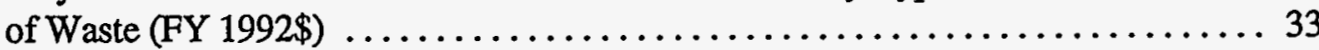

Figure 21: City of Seattle Total Waste (Tons) $\ldots \ldots \ldots \ldots \ldots \ldots \ldots \ldots \ldots \ldots \ldots \ldots \ldots \ldots \ldots \ldots$

Figure 22: City of Seattle Analyzed Waste by Type of Waste (Tons) $\ldots \ldots \ldots \ldots \ldots \ldots$

Figure 23: City of Seattle Net Costs of Managing Analyzed MSW by Functional

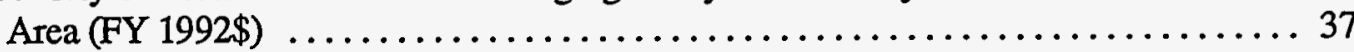

Figure 24: City of Seattle Allocation of Net Costs by Type of Waste (FY 1992\$) ........ 37

Figure 25: City of Seattle Functional Allocation of Net Costs by Type of Waste

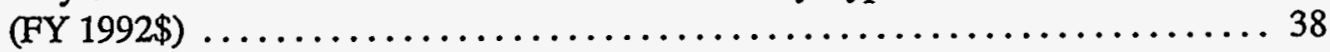

Figure 26: City of Sevierville Total Waste (Tons) $\ldots \ldots \ldots \ldots \ldots \ldots \ldots \ldots \ldots \ldots \ldots \ldots \ldots \ldots$

Figure 27: City of Sevierville Analyzed Waste by Type of Waste (Tons) $\ldots \ldots \ldots \ldots \ldots 41$

Figure 28: City of Sevierville Net Costs of Managing Analyzed MSW by Functional Area (FY 1993/94\$)

Figure 29: City of Sevierville Allocation of Net Costs by Type of Waste

(FY 1993/94\$)

Figure 30: City of Sevierville Functional Allocation of Net Costs by Type of Waste (FY 1993/94\$) . . . . . . . . . . . . . . . . . . . . 43

Figure 31: City of Springfield Total Waste (Tons) $\ldots \ldots \ldots \ldots \ldots \ldots \ldots \ldots \ldots \ldots$

Figure 32: City of Springfield Analyzed Waste by Type of Waste (Tons) $\ldots \ldots \ldots \ldots \ldots$

Figure 33: City of Springfield Net Costs of Managing MSW by Functional Area

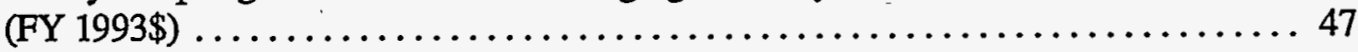

Figure 34: City of Springfield Allocation of Net Costs by Type of Waste (FY 1993\$) ... . 47

Figure 35: City of Springfield Functional Allocation of Net Costs by Type of Waste (FY 1993\$) 48 


\section{List of Tables}

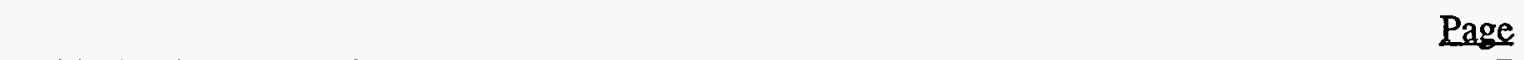

Table 1: Summary of Selected Costs by System Studied $\ldots \ldots \ldots \ldots \ldots \ldots \ldots \ldots \ldots 7$

Table 2: Populations Represented in the Case Studies $\ldots \ldots \ldots \ldots \ldots \ldots \ldots \ldots \ldots \ldots$

Table 3: City of Minneapolis - Average Cost Per Ton (FY $1992 \$) \ldots \ldots \ldots \ldots \ldots \ldots$

Table 4. City of Minneapolis - Program Incremental Costs (Savings) and

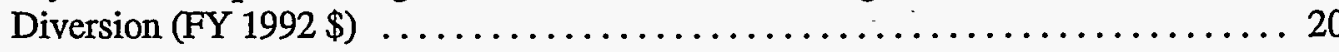

Table 5. City of Minneapolis - Energy Consumed to Collect Garbage, Yard Waste,

Bulky Waste, and Recyclables in the City (FY 1992) ................ 20

Table 6. Palm Beach County - Average Cost/Ton (FY $1992 \$$ )................ 24

Table 7. Palm Beach County - Program Incremental Costs (Savings) and Diversion (FY $1992 \$$ ) . . . . . . . . . . . . . . . . . . . . . . 25

Table 8. Palm Beach County - Energy Consumed to Collect Garbage, Trash,

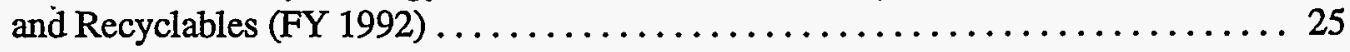

Table 9. City of Scottsdale - Average Costs Per Ton (FY $1992 \$) \ldots \ldots \ldots \ldots \ldots \ldots$

Table 10. City of Scottsdale - Program Incremental Costs (Savings) and

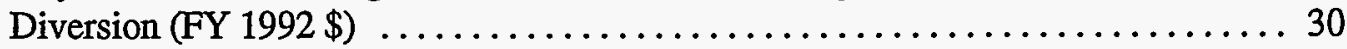

Table 11. City of Scottsdale - Energy Consumed to Manage Garbage, Brush, and

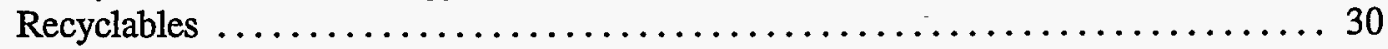

Table 12. City of Seattle - Average Costs Per Ton (FY $1992 \$) \ldots \ldots \ldots \ldots \ldots \ldots \ldots$

Table 13. City of Seattle - Program Incremental Costs (Savings) and Diversion (FY $1992 \$)$. . . . . . . . . . . . . . . . . . . . . . . 35

Table 14. City of Sevierville - Average Costs Per Ton (FY 1993/94 \$) . . . . . . . . . . 39

Table 15. City of Sevierville - Program Incremental Costs (Savings) and Diversion (FY 1993/94) ............................. 40

Table 16. City of Sevierville - Energy Consumption for Managing Analyzed MSW (FY 1993/94 Equivalent Diesel Gallons Per Ton) . .

Table 17. City of Springfield - Average Costs Per Ton (FY $1993 \$$ ) . . . . . . . . . 44 


\section{List of Tables (Continued)}

Table 18. City of Springfield - Program Incremental Costs (Savings) and

Page

Diversion (FY 1993 \$)

45

Table 19. City of Springfield - Energy Consumed to Collect Garbage, Bulky Waste, Office Paper, and Recyclables (FY 1993) 
$\because$ 


\section{Introduction}

This report presents principal findings from case studies of six operating integrated municipal solid waste management (IMSWM) systems. The primary purpose of these case studies was to develop and present consistent cost, resource use (especially energy), and environmental regulatory information on each operating IMSWM system. In the six case studies, integrated municipal solid waste management is defined as the practice of using two or more alternative waste management techniques, such as source reduction, recycling, composting, combustion, or landfilling, to treat, process, and/or dispose of the municipal solid waste (MSW) stream. A detailed report on each of the six systems is available as follows:

$\begin{array}{ll}- & \text { Minneapolis, Minnesota (Hennepin County); NREL/TP430-20473 } \\ \text { - } & \text { Palm Beach Count, Florida; NREL/TP430-8131 } \\ \text { - } & \text { Seattsdale, Arizona; NREL/TP430-7977 } \\ \text { - } & \text { Sevierville, Tennessee; NREL/TP430-8136, and } \\ \text { Springfield, Massachusetts; NREL/TP430-8137. }\end{array}$

This highlights the key lessons leamed and insights that can reasonably be derived from the combined case studies, and includes a detailed review of the analytical methods used. This synopsis supplements the information presented in each of the individual case studies, each of which should be reviewed carefully for complete details about the individual IMSWM systems.

The case studies do not compare the systems or system elements. The six IMSWM systems studied represent diversity in system complexity and geographic location. Each system studied is unique: the solid waste streams managed are different; the percentage of the total solid waste stream which was analyzed is different; the operational and ownership structures are different; and the state laws and regulations vary as well. Data analyzed in these systems are for a single fiscal year. However, the years vary among the six systems from 1992 to 1994 . Consequently, attempts to compare the findings of these six case studies with other work would have no common basis. Documentation of the case studies involved the development and application of analytical methods to use in collecting information on the following parameters for each IMSWM system:

- The types and quantities of municipal solid waste (MSW) managed;

- Total (average and functional ${ }^{1}$ ) costs as well as incremental costs (savings) for each major component of the IMSWM system;

- Energy use; and

- Environmental and safety regulations and legislation.

\footnotetext{
1 Finctional areas varied for each system, but included one or more of the following: garbage collection, residential recyclables collection, commercial recyclables collection, vegetative waste collection, compost processing, recyclables processing, landfilling, combustion and G\&A.
} 


\section{Terms and Definitions}

Following are key terms with their definitions used in the case studies.

\begin{tabular}{ll}
\hline \multicolumn{1}{c}{ Term } & \multicolumn{1}{c}{ Definition } \\
\hline Analyzed MSW & $\begin{array}{l}\text { That portion of the total MSW stream for which the associated management net } \\
\text { costs are known, or at a minimum, can be reasonably estimated. The reason for } \\
\text { limiting the types of MSW included in Analyzed MSW is to include only that } \\
\text { portion of MSW for which sufficient data were available to draw defensible } \\
\text { conclusions regarding the allocation of cost to the tons of MSW managed. } \\
\text { Consequently, the types of MSW included in Analyzed MSW vary between } \\
\text { IMSWM systems. }\end{array}$ \\
Garbage & $\begin{array}{l}\text { The MSW remaining after source separation of recyclables, yard waste, } \\
\text { household hazardous waste, and bulky waste. }\end{array}$ \\
Municipal Solid Waste \\
(MSW)
\end{tabular} $\begin{aligned} & \text { Non-hazardous solid wastes (with the exception of household hazardous waste) } \\
& \text { generated by households, businesses, institutions, and light industry } \\
& \text { (administrative, cafeteria, packaging, etc.), including ash from the combustion } \\
& \text { of MSW. Types of solid waste excluded from the definition of MSW are } \\
& \text { industrial process waste, construction and demolition debris, offal, sludges, tires, } \\
& \text { and ashes, except ashes from the combustion of MSW. }\end{aligned}$

\section{Discussion of Cost Terminology}

The definitions of Total, Average, and Program Incremental Costs and their inter-relationships, are illustrated using the simplified hypothetical cost curves in Figures 1 through 3 . Although these simplified cost functions facilitate an understanding of these inter-relationships, they also serve, by providing counter examples, as a mathematical proof that certain relationships do not exist.

For the hypothetical municipal solid waste management system depicted in Figure 1, 176,800 tons of garbage are collected and disposed for a Total Cost of $\$ 26.75$ million. This results in an Average Cost per Ton of $\$ 151$ (i.e., $\$ 26,750,000$ divided by 176,800). The Total Net Cost is the sum of $\$ 13.58$ million of fixed costs, such as capital and $\mathrm{G} \& \mathrm{~A}$ costs, and $\$ 13.17$ million of 
Figure 1. Total and Average Costs Before Adding a New Program

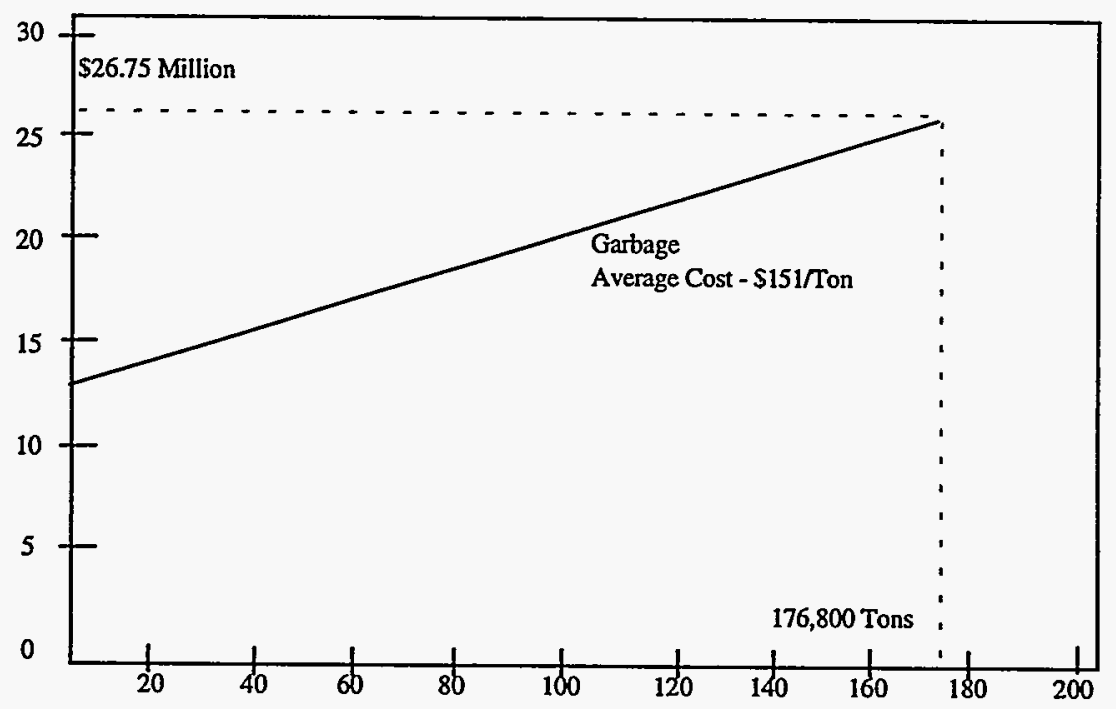

Figure 2. Total and Average Costs of MSW and Yardwaste Programs

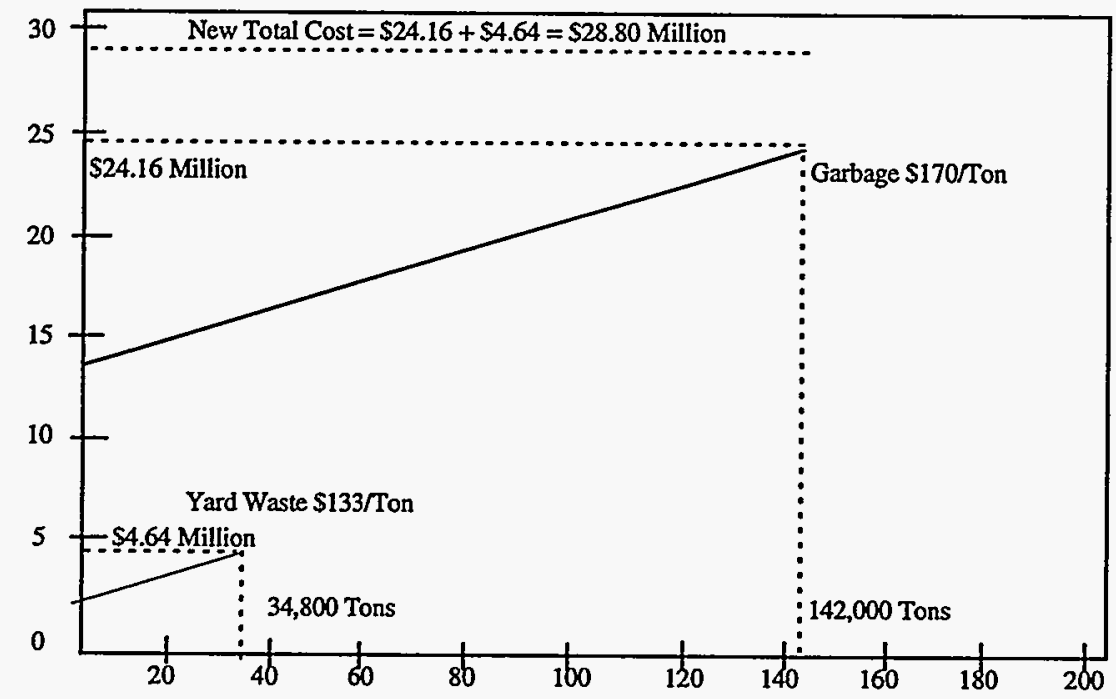

Figure 3. Total, Average, and Incremental Costs of MSW and Yard Waste Program:

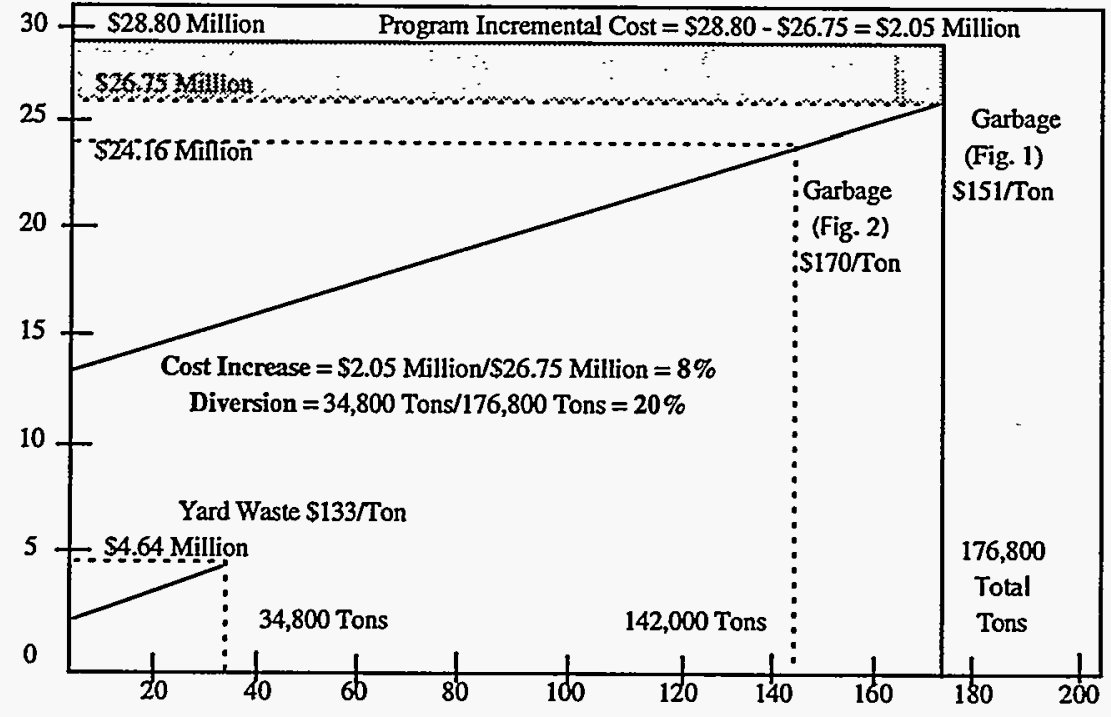


variable costs, such as labor, fuel, tipping fees, and/or $O \& M$ costs. The variable cost per ton is $\$ 74.50(\$ 13,170,000$ divided by 176,800$)$.

This example is one way to illustrate that the Average Cost per ton of garbage collection and disposal does not represent the costs that are "avoidable" for each ton of waste which may be diverted from the waste stream. For example, in this illustration, the hypothetical community can avoid only the variable cost portion $(\$ 74.50)$ per ton for every ton diverted from the municipal solid waste stream, not the average cost per ton of $\$ 151$. This occurs because certain fixed costs can not be reduced as materials are diverted from the municipal solid waste stream. Only the variable costs per ton can be saved for each ton diverted. In more complex situations, as more and more materials are diverted from the solid waste stream and/or time passes to allow contracts to be changed or equipment to be replaced, some fixed costs can be reduced as well, but not necessarily in proportion to the tonnage diverted. The degree to which fixed costs can be reduced varies from place to place.

Figure 2 illustrates what happens if this hypothetical community institutes a solid waste diversion program, in this case a yard waste source separation collection and composting program. (A similar example to illustrate the analysis could have been formulated for a recyclables collection and processing program, or a waste to energy program.) To divert 34,800 tons of yard waste, the hypothetical community spends a Total Net Cost of $\$ 4.64$ million, or an Average Cost per Ton of $\$ 133$ (i.e., $\$ 4,640,000$ divided by 34,800 tons). In this case, the community has been able to reduce the Total Net Cost for collecting and disposing of the remaining 142,000 tons of garbage from $\$ 26.75$ million to $\$ 24.16$ million, a difference of $\$ 2.59$ million. However, when expressed as a cost per ton, the average cost of garbage collection and disposal has changed from $\$ 151$ to $\$ 170$ per ton because the fixed costs, which were unchanged, were allocated over fewer tons. More importantly, however, for this integrated MSWM system the community is now spending $\$ 28.80$ million ( $\$ 24.26$ million for garbage, plus $\$ 4.64$ million for yard waste), or $\$ 2.05$ million more than it was spending before addition of the yard waste program.

The Program Incremental Cost is defined as the difference between the cost of managing MSW with or without the inclusion of a particular program. As shown in Figure 3, the incremental cost of yard waste diversion in this hypothetical community is $\$ 2.05$ million, the difference between the $\$ 28.80$ million Total Net Cost for the integrated system and the $\$ 26.75$ million cost for the system without the yard waste program.

Although the $\$ 133$ average cost per ton for the yard waste program is less than the $\$ 170$ average cost per ton for garbage collection and disposal, the inclusion of the yard waste program results in an overall increase of 8 percent ( $\$ 2.05$ million divided by $\$ 26.75$ million) in the community's expenditures on municipal solid waste management. The institution of this program resulted in the diversion from landfill of 20 percent (by weight) of the municipal solid waste stream.

This example, with the accompanying figures, is presented to illustrate the differences between all the various expressions of cost, and to show that a lower average cost per ton for a specific program does not necessarily reflect an overall savings related to instituting that program. Similarly, it is not necessarily true that a community is increasing its expenditures for a diversion program if the average cost per ton of the diversion program is greater than the average cost per ton of garbage collection and disposal. In general, the comparison of average cost per ton between programs in an integrated 
system does not provide any insights into the economic impact of any program on the overall cost of an integrated solid waste management system.

Calculation of program incremental cost is a more appropriate means of expressing the cost/benefit relationships for resource recovery and diversion programs. In this hypothetical example, the increase in expenditures of 8 percent allowed for a diversion from landfill of 20 percent of the municipal solid waste stream. In the discussions of the individual case studies which begin on Page 18, this cost/benefit relationship is shown for each resource recovery or diversion program. Diversion occurs when reliance on landfills is reduced through the beneficial use of waste derived resources.

Cost and diversion information were developed in the case studies. However, because data considered in these case studies were for less than 100 percent of the total municipal solid waste stream in any given integrated MSWM system, these data cannot be used to compute either recycling rates or diversion rates which may be required by state laws. Case study data were not collected for that purpose and will not be sufficient for that purpose. For example, self-haul recyclables, commercial waste collection, disposal or recycling, and any backyard composting that might contribute to state diversion goals may not be considered in these case studies.

Complex jurisdictional relationships applied in most of the integrated MSWM systems studied. In several case studies, jurisdictions depended upon each other for different elements of the integrated system. However, the degree of interdependency varied from place to place. These interdependencies complicate cost analysis, and because these relationships differ markedly from place to place, comparisons between different integrated MSWM systems are impractical.

\section{Lessons Learned}

This section summarizes the significant general findings and conclusions derived from studying the data and results presented in the case studies. Specific numerical results for each case study are presented in subsequent sections.

Calculate the Program Incremental Cost to Determine the Cost or Benefit of Adding (or Changing) a Program in an Integrated MSWM System. The case studies illustrate the decisionmaking advantages (in fact, the necessity) of examining program costs on an incremental basis. Although the case studies considered data for a single year, decision makers and planners would gain a better understanding of the long-term cost impacts of various programs if incremental costs were projected for each year of the planning period, e.g., five or ten years.

While demonstrating the use of incremental cost analysis, the case studies also illustrate that comparing the average cost per ton of managing garbage to the average cost per ton of diversion or resource recovery programs is inappropriate and can lead to erroneous conclusions. Because

many local, state, provincial, and federal planning and regulatory organizations use or suggest the use of average cost comparisons to reach conclusions on the relative costs of various programs, the 
importance of this lesson cannot be overstated. $^{2}$

Whenever Materials are Diverted from the Waste Stream, a Local Government Should Examine Whether it can Reduce Expenditures for the Basic Program of Municipal Solid Waste Collection and Disposal. If savings can be realized in the basic program, then the cost differences attributable to a diversion program 'can be reduced, i.e., the program incremental cost can be reduced. For example, in the case study for Seattle, it is shown that Seattle's residential curbside and yard waste programs' incremental costs are relatively low because of savings Seattle was able to realize in the collection and disposal of municipal solid wastes. Seattle was able to realize these savings because both its collection and disposal contracts are tonnage based. That is, for every ton diverted from the municipal solid waste stream, the City saves on both its collection and its disposal costs for garbage. On the other hand, other case studies show relatively higher recycling or yard waste program incremental costs, partly because little or no savings were realized in solid waste collection and disposal.

There are several impediments to realizing these savings, at least in the short term, including routing or equipment constraints, union rules, contract limitations, service level limits, etc. For example, many communities in Palm Beach County pay for Residential Solid Waste (RSW) collection on a per household basis. When the residential curbside recycling program was instituted, many of the citybased RSW collection contractual fees were not renegotiated. Therefore, until the next round of bids, there was no savings in collection costs for MSW. Springfield's curbside recycling program incremental cost is also relatively high, in part because its "put-or-pay" commitment makes it impossible to realize any disposal cost savings at the waste-to-energy facility.

High Incremental Cost Does Not Necessarily Mean That A Diversion or Resource Recovery Program is not Well-Designed and Operated. An incremental cost is the difference between two costs. Therefore, the lower the variable cost per ton of municipal solid waste collection and disposal in a community, the more likely it will be that the incremental cost of a new diversion or recycling program will be high. For example, in cities like Scottsdale and Sevierville, where collection costs are low, and landfill costs are also low, the incremental cost of any program would be expected to be relatively high, no matter how well-designed or efficient it is.

Collection of Either MSW, Recyclables or Yard Waste Represents the Most Significant IMSWM System Cost. In each case study, collection costs consistently account for the largest percentage of total IMSWM system net costs. Collection costs dominate whether the system uses several management options or just one or two. Collection costs, exclusive of transfer and haul costs, as shown in Table 1, range from 39-62 percent of the total system costs. With the expansion of materials and energy recovery services over the past two decades, it is interesting that the costs for processing facilities (e.g., waste-to-energy, materials recovery facilities, yard waste and MSW composting) were not the dominant cost elements. Rather, collection remains the largest cost element of IMSWM systems.

\footnotetext{
${ }^{2}$ For example, in a recent report, the federal EPA subtracts the average cost of collecting and disposing of garbage from the average cost of collecting and processing recyclables, and as a result, may have erroneously reported the net savings (cost) per ton of recycling programs. Report to Congress, Flow Controls and Municipal Solid Waste, Office of Solid Waste, Municipal and Industrial Solid Waste Division, March 1995, Exhibit III-18, EPA-530-R-95008).
} 
process, and haul these materials.

Waste Diversion, Recycling and Resource Recovery Programs Tend to Increase the Cost of Municipal Solid Waste Management. Except for the curbside recycling program in Seattle, all of the curbside recycling, yard waste composting, waste-to-energy, and mixed waste composting programs analyzed increased the cost of managing MSW in the case study communities, shown in Figure 4. Three of the four curbside recycling programs analyzed increased system costs from 5-12 percent. ${ }^{3}$ Seattle's curbside recycling program slightly reduced costs. These programs diverted from 9 to 21 percent (by weight) of the solid waste stream in those communities. ${ }^{4}$ Higher levels of diversion from these residential curbside recycling programs occurred in Seattle and Minneapolis where residents have economic incentives (variable rate garbage fees or tax breaks) for participation in the program. The three curbside yard waste collection and composting programs resulted in increased overall system costs, which ranged from 2-4 percent while achieving diversion of 11-20 percent (by weight). The three waste-to-energy resource recovery programs analyzed increased overall IMSWM costs from 3-18 percent, while diverting 38-50 percent (by weight) from the solid waste stream. Finally, the only mixed waste composting program analyzed increased overall IMSWM system costs by 25 percent, but diverted approximately 70 percent (by weight) of the analyzed solid waste stream from landfill disposal.

\section{Approach}

Because no standard cost or energy accounting practices are used across the U.S., two methods were developed and applied in the case studies, one for analyzing costs and the other for analyzing energy consumption. Both methods were applied to only a one-year period. However, both methods can be expanded to yield life-cycle incremental cost analyses.

To develop and apply the methods, study boundaries were established, which included all activities associated with collection (from the curb), processing, disposal, transport and shipping to the end-user or remanufacturer. Specifically excluded from the study boundaries was energy consumption associated with the manufacture of goods in the waste stream or their remanufacture/reuse through recycling.

Each method.is addressed below.

\section{Gross, Net and Incremental Cost Methods}

The method used in the case studies for analyzing gross, net and incremental costs of the

\footnotetext{
${ }^{3}$ These results apply to either FY 1992 or FY 1993, when commodity prices were relatively low. Since then, paper prices, in particular, have increased dramatically, which could alter these results in some of the communities.

4 Although the communities with the greatest diversion tended to have the lowest incremental cost, at this time no generalization can be made between incremental cost and diversion.
} 
Figure 4. Incremental Costs and Diversion for Selected Programs, as a Percentage of the Total ${ }^{\star}$

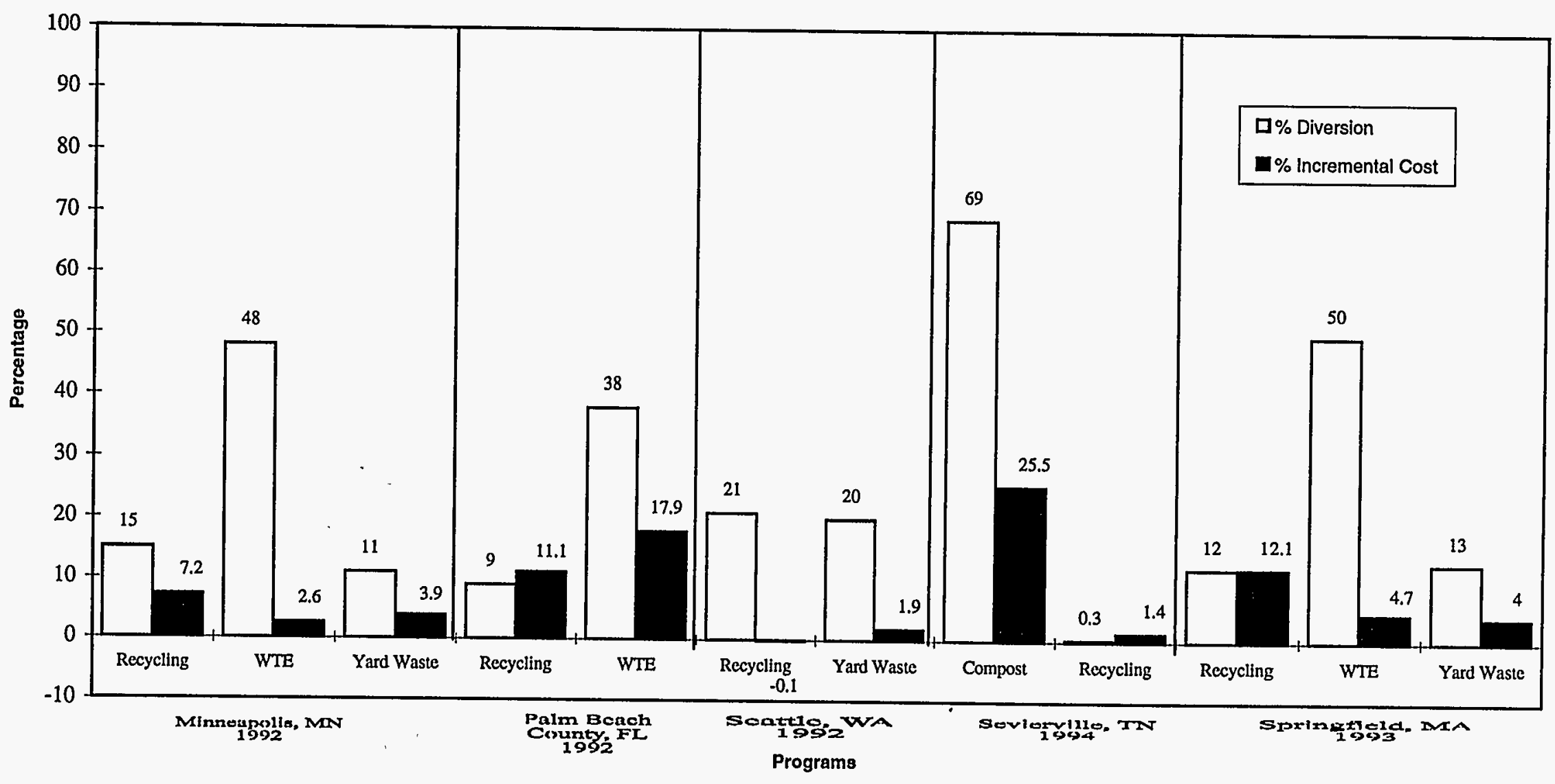

* For Analyzed Waste Stream Only. 
IMSWM systems and components is described in this section. The method was developed to:

- Identify total costs;

- Identify total revenues;

- Establish a means of reasonably allocating costs and revenues to the MSW stream managed;

- Establish a means to further allocate those costs by the IMSWM system's functional areas and type of waste managed; and

- Determine incremental costs.

Certain obstacles were encountered in determining costs on a consistent basis for the six IMSWM systems presented in the case studies:

The institutional structure of the six IMSWM systems varied and consisted of one or a combination of the following: publicly-operated collection systems, privatelyoperated collection systems (operating independently or under contract to public entities), public or private facility operators, inter-governmental solid waste authorities, etc.

Currently, no standard accounting procedure has been adopted in the United States for MSW management, nor have definitions of terminology associated with MSW management practices been standardized.

Local governments by tradition and practice maintain their financial records in a variety of ways to best suit the specific needs of the local government, which may not serve the needs of measuring the costs of the entire IMSWM system. It was common to find that IMSWM systems were funded from general revenues, and therefore, the specific system costs were not typically consolidated, which resulted in no record of the total costs of a system. Thus, it was common to find that tracking the full costs associated with a given system or component of a system was difficult based on the records available.

For example, in some cases, publicly-operated collection systems used vehicle maintenance and repair facilities that provided service to a system-wide fleet of vehicles, including other vehicles, such as police and staff vehicles. While the costs of the maintenance facility may have been well documented, sufficient records may not have been maintained to allocate these costs or fuel usage back to individual vehicle functions, such as the garbage collection fleet. The analysis made adjustments to account for these costs. Another area where analysis was difficult relates to fringe benefits costs of public employees. In some cases, these costs were not reported and had to be calculated and added in. Thus the costs calculated in the case studies include fringe benefits, but may not conform to local reported costs.

The cost method consists of several steps as shown graphically in Figure 5. Each step is discussed below. A method was also developed for determining the incremental cost of a given system component or program. This method is also discussed. 
Figure 5. Cost Methodology for Determining Gross and Net Costs and for Allocating Total Costs by Functional Area and Waste Type

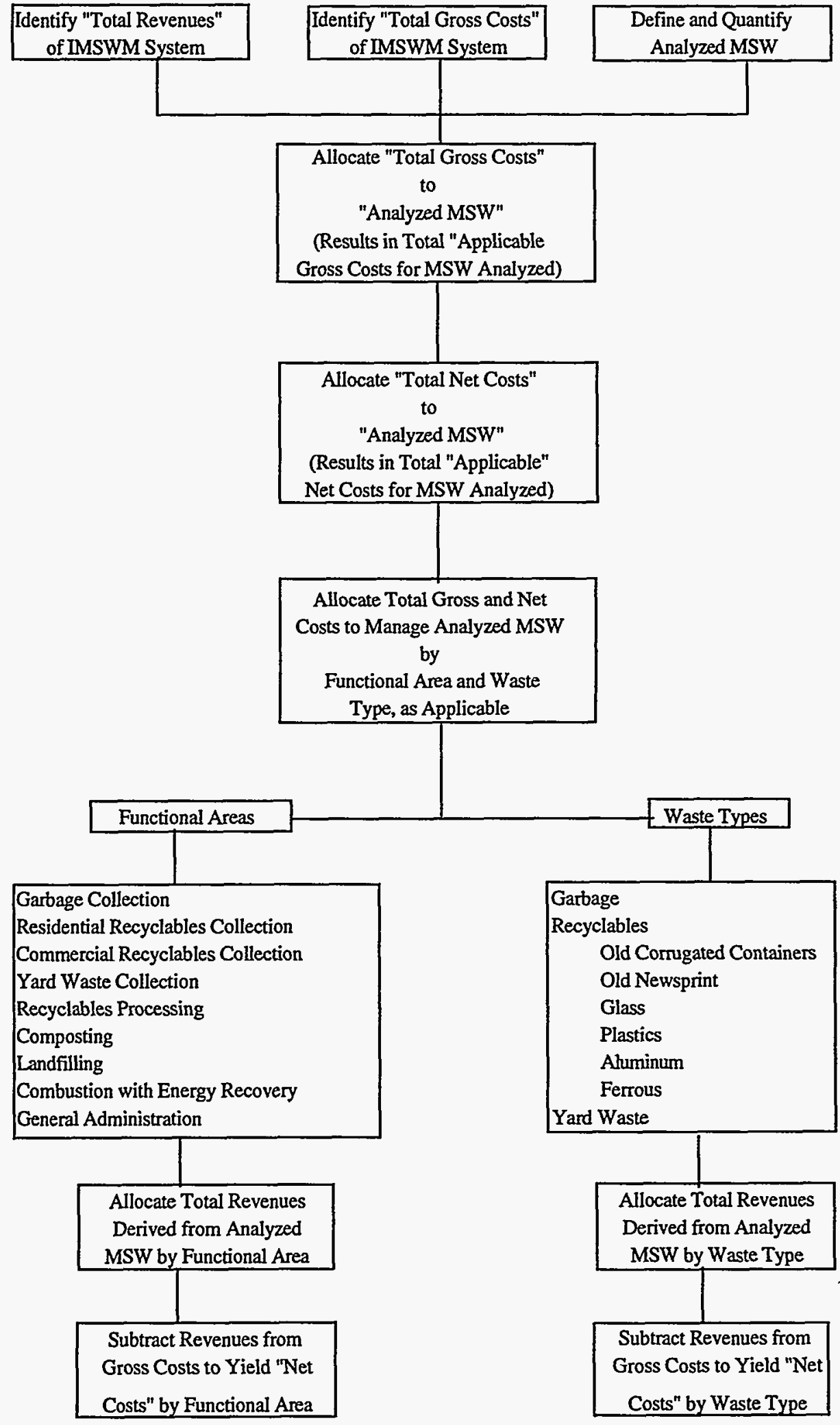




\section{Define and Quantify "Analyzed MSW"}

A critical element of the cost analysis was an attempt to document costs for different functions (collection, transfer, processing, disposal, etc.) which support an IMSWM. Analyzed MSW is defined as that portion of the total MSW stream for which the associated management costs can be determined or, at a minimum, reasonably estimated. The reason for limiting the types of MSW included in Analyzed MSW was to include only that portion of MSW for which sufficient cost data was available to draw defensible conclusions regarding the allocation of cost to the tons of MSW managed. Consequently, the types of MSW included in Analyzed MSW varied between IMSWM systems. Specifically, analyzed MSW may include none, some, or all of the commercial MSW generated in the community.

In performing the case studies, the most common reason for excluding portions of the MSW stream was a lack of collection cost data. The programs most commonly impacted were MSW and recyclables from commercial, institutional, and light industrial sources, and certain drop-off recyclables, yard waste and HHW drop-off programs.

\section{Identify Total IMSWM System Gross and Net Costs}

An attempt was made to identify all sources of costs and revenues to determine total IMSWM system gross and net costs (net costs are gross costs less revenues). Typically, revenues were easily identified and readily documented. Costs included the direct costs associated with the entities specifically responsible for MSW management, such as a sanitation or public works department, solid waste authorities, private contractors (private haulers and facility operators), and the less obvious indirect costs associated with ancillary departments, private contracts or other federal, state or local entities. The case studies suggest that the most difficult cost to identify and quantify was general and administrative (G\&A) costs, such as shared office space, office equipment and staffing resources like city/county attorneys and administrators. It was important to identify these costs, since, if these resources were not made available, additional costs would be incurred by the system. Therefore, the benefits derived from these resources were reflected as a cost to the system and allocated to the system.

The most reliable sources of cost and revenue data were found to be audit data, financial statements, annual reports, or other types of audited accounting records. Therefore, the most important first step was to identify and interview accounting staff to acquire reliable data, and equally important, to gain knowledge of how the funding mechanisms worked. The accounting staff were able to identify costs and revenues not otherwise accounted for, and were able to explain how monies flowed in and out of the system. As a next step, the program staff was interviewed to review the accounting data and offer clarification of program related issues. Once the basic cost and revenue data were acquired and understood, they were then adjusted as appropriate.

\section{Adjust Total IMSWM System Gross and Net Costs}

Two adjustments to the costs and revenues were typically required regardless of the institutional structure used. 
The first adjustment was to annualize or capitalize capital expenses ${ }^{5}$ over the useful life of the asset. With this approach, the capital cost of an asset is independent of the method used to pay for the asset and has the same annual value over the useful life of the asset. This was an important adjustment, because otherwise the cost of an IMSWM system for a single one-year period could lead to distorted results. For example, assume a new front-end loader with a seven-

year life was purchased for $\$ 100,000$ in cash to serve a small corrugated recycling facility. Without making this adjustment, the financial statements would allocate the entire cost to a single one-year period and thus distort the cost analysis to indicate an unreasonably high cost in that given year and lower than expected costs in other years.

Annualizing or capitalizing a capital expense was a reasonable approach to use for capital expenses associated with buildings and equipment, which represented the majority of the capital assets that comprised the IMSWM systems. However, the preceding approach was not applicable to landfills. The useful life of a landfill is not dependent on the age of the landfill, but rather can be correlated to the level of consumption or use of the landfill's capacity. Therefore, the initial capital costs associated with developing a landfill were allocated to the volumetric capacity of the landfill (i.e., dollars per cubic yard). The annualized capital cost of the landfill was then determined by multiplying this unit cost (escalated to the appropriate year's dollars to adjust for effects of inflation) by the volumetric capacity consumed in a given year.

The second adjustment made was to revenues. Financial statements included revenues, such as landfill and other processing facility tip fees, designated assessments, and other fees. However, the actual net cost (gross costs less revenues) of any IMSWM system is the gross costs less only those revenues paid into the system from the sale of recyclable materials, compost, energy or other marketable end-product. Therefore, when a private entity received a share of material or energy revenues, the private entity's share was accounted for as a revenue paid into the system. This required the associated cost (or payment) to the private entity to be increased by an amount equivalent to the revenue share. This approach was based on the assumption that the revenue share offsets associated costs of the private entity.

\section{Determine Applicable Costs/Revenues}

The total adjusted costs/revenues were then allocated to the Analyzed MSW. This was a relatively straightforward step requiring that the costs associated with excluded waste also be excluded. For example, the costs associated with Class IV construction/demolition landfills would typically be excluded because this type of waste is not considered MSW. Another example would be the exclusion of the costs associated with any drop-off program, because this program and this waste was excluded from Analyzed MSW due to a lack of cost data on the self-haulers required to make this program functional. It was possible to allocate some costs between Non-Analyzed and Analyzed MSW using factors such as tonnage.

\section{Allocate Adjusted and Applicable Gross and Net Costs to IMSWM System's Functional Areas}

Adjusted and applicable costs/revenues were allocated to the functional areas of the IMSWM system. Functional areas varied for each system, but included one or more of the following: garbage

\footnotetext{
5 The purchase of an asset or service with a useful life of greater than one year.
} 
collection, residential recyclables collection, commercial recyclables collection, vegetative waste collection, compost processing, recyclables processing, landfilling, combustion and G\&A.

Allocating costs by function required a review of each line item's cost/revenue. Often it was possible to allocate 100 percent of a specific cost/revenue to a given functional area. Other times it was necessary to allocate a given cost/revenue among functional areas. The method of allocating between functional areas depended on the line item being allocated. For example, the cost of a commercial recyclables collection truck could be allocated 100 percent to the commercial recycling function, whereas the total cost of diesel fuel may have needed to be allocated between the garbage and recycling collection functions.

\section{Allocate Adjusted and Applicable Costs/Revenues by Solid Waste Type}

Adjusted and applicable costs/revenues were allocated by solid waste type, which varied for each system, but included one or more of the following: garbage, recyclables and/or, yard waste. Each costs was allocated to waste type using the same method as allocation by functional area. If an expense or revenue was wholly attributable to a single waste type, e.g., a MRF for recyclables, it was allocated entirely to that waste type. If an expense or revenue needed to be allocated to more than one waste type, e.g., transfer station costs where garbage, yard waste, and recyclables are transferred, it was allocated to the respective waste types based on tonnage, staffing levels, or other appropriate variables. G\&A expenses were allocated based on the dollars expended on non-G\&A functions.

\section{Program Incremental Costs (or Savings)}

A Program Incremental Cost (or Savings) is defined herein as "the difference between the cost of managing MSW with or without the inclusion of a particular program." An incremental cost was calculated for each program by assuming that the program had never been implemented and determining what the cost impact on the system would have been if the program had never been implemented. The system "Without Program" cost was then subtracted from the "With Program" cost to determine the incremental cost of the program. It was assumed that prevailing market prices and conditions are applicable for all activities.

This concept can be demonstrated in a simplified way by assuming an IMSWM system currently consists only of a garbage collection system, landfill and mixed MSW composting facility. Assuming that the landfill and compost facility are located adjacent to one another, it is reasonably correct to assume that the cost of garbage collection would be the same if the compost facility did not exist. If the compost facility did not exist, then all the costs associated with the compost facility would be eliminated. However, assuming the compost facility did not exist means that all the solid waste would be handled at the landfill, which would increase the costs associated with landfilling. Therefore, the incremental cost of the compost facility is the difference between the compost facility cost (C) plus the landfilling costs $\left(\mathrm{L}_{1}\right)$ under a combined compost-landfill system, minus landfilling costs $\left(\mathrm{L}_{0}\right)$ under a system with no composting since more waste would be handled at the landfill. This can be shown as:

$$
\left(\mathrm{L}_{1}+\mathrm{C}\right)-\mathrm{L}_{0}=\text { Program Incremental Cost of Composting }
$$

It should be noted that in some instances, legislative requirements preclude the actual ability to eliminate certain programs. For instance, the landfilling or incineration of yard waste is banned in many states. In cases such as these, the incremental cost can be interpreted as reflecting the cost (or 
savings) of the ban.

\section{Energy Method}

The method developed in the case studies for analyzing the energy consumption of various IMSWM system components is described in this section. The IMSWM system components included in the energy consumption analyses were as follows:

- $\quad$ Collection vehicles for garbage, recyclables, yard waste, and bulky wastes;

- Transfer stations and hauling of MSW between facilities and transfer stations;

- Processing/combustion facilities, including MRFs, composting facilities, and WTE facilities;

- Landfills; and

- The transportation of processed recyclables and compost.

The method focused on energy consumption and briefly considered energy generation for those systems with WTE components. In general, the results of the analyses were presented in equivalent ${ }^{6}$ gallons of diesel fuel consumed per ton of MSW. Such information was presented by system component (collection, material recovery facility, transfer station, etc.) and type of MSW (garbage, recyclables, yard waste, etc.).

\section{Types of Energy Included and Excluded from Analysis}

Certain types of energy consumed or conserved were excluded from the energy consumption method. Energy consumed or conserved in the remanufacture of recyclables into usable products was outside the study boundaries. These factors, however, must be considered when assessing the overall energy consequences of recycling. In addition, energy consumed for self-hauling garbage, recyclables, yard waste, etc., to drop-off sites or facilities was generally excluded.

All other energy types directly consumed by the IMSWM system components were used in the analyses. Following are the various energy sources considered in the analysis:

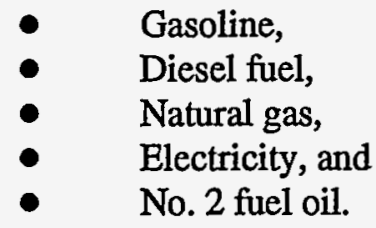

\section{Calculation of System Component Energy Usage}

Energy consumption data were collected for the various components of the IMSWM systems. If such data were not available, either assumptions were used to estimate energy usage or energy consumption was not.included. The energy usage by each component was then converted into total British thermal units (Btus), and then into equivalent gallons of diesel fuel using standard conversion factors.

For those system components that handled MSW imported from outside the IMSWM system, the amount of energy consumption attributable to MSW generated in the system was determined by prorating energy consumption based on tonnage. For each system component (landfilling,

\footnotetext{
${ }^{6}$ Equivalent energy or Btu value expressed in terms of gallons of diesel fuel.
} 
composting, etc.), the energy usage by type of solid waste (garbage, yard waste, recyclables, etc.) was then estimated.

If a system component handled more than one type of MSW, the amount attributable to each type of MSW was generally determined by prorating the energy usage based on tonnage. Because some collection vehicles were used for more than one type of solid waste, energy usage by those vehicles was generally prorated based on an estimated breakdown of time the vehicles were used to collect each type of solid waste.

Finally, the total equivalent diesel gallons per ton and Btus per ton were calculated by type of solid waste. Also, equivalent diesel gallons per ton were calculated by type of system component.

\section{Calculation of Energy Use for Hauling}

A different approach was used to estimate energy consumption for hauling recyclables and compost to markets than for hauling other materials such as garbage. (Markets are defined as the first processing point reached after leaving the system.) It should be noted that energy consumption was analyzed only when recyclables were hauled to markets using tractor trailers (railroad and ocean shipping approaches were excluded from the analyses). In order to estimate the energy consumption for hauling recyclables to markets, a weighted average distance for each type of recyclable hauled was established. A conversion factor of gallons per ton-mile was then used to estimate energy consumption. The conversion factor was based upon actual energy consumption of MSW/transfer vehicles.

In some case studies, it was not possible to determine a weighted average distance to markets. Therefore, ranges of miles were given and then converted to ranges of gallons per ton hauled based on the gallon per ton-mile conversion factor.

The energy consumed to haul compost to markets was estimated by assuming the compost was hauled in dump trucks. Based on assumed or actual cubic yard capacities of the dump trucks, bulk densities of the compost, quantities of compost, miles per gallon of diesel used, and miles to the market, the estimated gallons of diesel consumed per year to haul the compost was determined. This quantity was then divided by the quantity of Analyzed MSW composted to determine the equivalent gallons per ton.

\section{Calculation of Energy Use/Production for WTE Facilities}

For WTE facilities, the quantity of energy used was obtained. In-house use of electricity was identified separately from other types of fuel use. The energy use was then converted into equivalent gallons of diesel fuel using standard conversion factors. If the WTE facility handled MSW imported from outside the system, the amount of energy consumption attributable to MSW from inside the system was determined by prorating it based on tonnage.

Energy production at the WTE facilities was also analyzed and converted into equivalent gallons of diesel fuel conserved per ton managed. The quantity of electricity sold was converted to equivalent gallons of diesel fuel, assuming a standard plant heat rate (Btu per kilowatt hour) for all studies. The estimate of energy produced is equal to the gallons of diesel fuel that would have been used to produce the same quantity of electricity by a utility. 
In the case where steam was also sold (Springfield), the quantity of steam sold was converted to equivalent gallons of diesel fuel per ton of garbage processed, assuming a standard boiler efficiency and specific enthalpy ${ }^{7}$ value based on reported steam conditions. Other steam losses were not considered. The analysis assumed that no condensate was returned from the steam market.

7 Enthalpy is a measure of the energy content of a system per unit of mass. 


\section{IMSWM System Descriptions and Results}

\section{Population}

The study included IMSWMS systems of different sizes serving different populations across the United States. Table 2 shows the range of populations represented in the case studies.

Table 2. Populations Represented in the case studies

\begin{tabular}{lcc}
\hline Location & $\begin{array}{c}\text { Population } \\
\text { (approximate) } \\
\text { County }\end{array}$ & $\begin{array}{c}\text { Population } \\
\text { (approximate) } \\
\text { City }\end{array}$ \\
\hline Minneapolis, Minnesota (Hennepin County) & $1,030,000$ & 368,000 \\
Palm Beach County, Florida & 897,000 & N/A \\
Scottsdale, Arizona & $2,100,000$ & 137,590 \\
Seattle, Washington & $1,500,000$ & 516,000 \\
Sevierville, Tennessee & 54,600 & 7,500 \\
Springfield, Massachusetts & 450,000 & 157,210 \\
\hline
\end{tabular}

\section{Economies, Institutional Arrangements, System Components, and Results}

For each case study, a brief summary of the following items is presented in this subsection:

\section{Economy}

The economy of an area has a direct impact on the quantity and constituents of MSW generated and the types of components that are most feasible in an IMSWM system.

\section{Institutional Arrangements}

It is important to understand the key institutional arrangements surrounding the management of the IMSWM systems outlined in the case studies, since the various institutions form the core of most of the IMSWM systems. It should be noted that the impacts on institutional arrangements due to the Supreme Court decision, Carbone v. Clarkstown, regarding flow control may not be reflected in the following summaries.

\section{System Components}

The IMSWM system components represented in each case study are briefly described. The descriptions highlight the types of components represented in each IMSWM system, however, the specifics of each component vary significantly, and therefore, the detailed case studies should be reviewed for specific information.

\section{Results}

The results of the cost and energy analyses are presented for each case study. 


\section{Minneapolis (Hennepin County), Minnesota}

\section{Economy}

This area has a relatively diverse economy. In 1992, three industry types - manufacturing, wholesale and retail trade, and services -- accounted for nearly 70 percent of the jobs in the seven-county Twin City metropolitan area.

\section{Institutional Arrangements}

The Minnesota Waste Management Act (WMA) was passed by the Minnesota legislature in 1980. Under the WMA, each of the seven metropolitan area counties is required to develop a solid waste master plan. In the metropolitan area, Minnesota cities and counties have shared responsibilities for implementing an IMSWM system consistent with the WMA. In Minneapolis and Hennepin County, the collection of various solid waste materials is primarily a city-sponsored service and the processing and disposal of MSW is primarily a county-sponsored service.

\section{System Components}

The city and county's IMSWM system components include, among others, curbside/alley residential and commercial garbage, recyclables, and yard waste collection services, along with specified HHW collection days, and a HHW drop-off site. There are also drop-off sites for tires, paving and construction materials and used oil; transfer stations (with one designated for yard waste); and a bulky waste processing area. The system components also include a mass-burn WTE facility, three refusederived fuel (RDF) waste processing facilities, and a private processing facility for recyclables operating under contract with the city. There are several private operations that process residential source-separated yard waste under contract. The county has contracts with a variety of regional and out-of-state landfills for the disposal of residue, non-processible waste, bypass waste, and ash.

\section{Results}

Figures 6, 7, 8, 9 and 10 graphically present the results of the cost of Analyzed MSW management for Minneapolis (Hennepin County). The average net cost to manage 142,907 tons of Analyzed MSW was $\$ 167$ per ton, in fiscal year 1992 dollars The following table illustrates the average cost per ton for each category of waste analyzed.

Table 3. City of Minneapolis - Average Cost Per Ton (FY 1992 \$)

\begin{tabular}{lccc}
\hline \multicolumn{1}{c}{ Category } & Tonnage & Total Cost & Average Cost/Ton \\
\hline Garbage & 102,030 & $16,918,500$ & $\$ 166$ \\
Recyclables & 21,500 & $3,645,150$ & $\$ 170$ \\
Yard Waste & 16,160 & $2,554,000$ & $\$ 158$ \\
Bulky Waste & 3,220 & 680,670 & $\$ 211$ \\
Total/Average & $\mathbf{1 4 2 , 9 0 7}$ & $\mathbf{2 3 , 8 0 0 , 0 0 0}$ & $\$ 167$ \\
\hline
\end{tabular}

8 This case study and analysis was prepared based upon information provided by the City of Minneapolis, Hennepin County, and several private companies which support the IMSWM system. The analysis has been reviewed and revised based upon comments provided by Hennepin County. 
The incremental program costs (savings) are shown below:

Table 4. City of Minneapolis - Incremental Program Costs (Savings) and Diversion (FY 1992 \$)

\begin{tabular}{|c|c|c|c|c|c|}
\hline & \multirow[t]{2}{*}{$\begin{array}{r}\text { Tons } \\
\text { Managed }\end{array}$} & \multicolumn{2}{|c|}{$\begin{array}{c}\text { Incremental Costs } \\
\text { (Savings) }\end{array}$} & \multicolumn{2}{|c|}{$\begin{array}{c}\text { Diversion from } \\
\text { Landfill }\end{array}$} \\
\hline & & $\$$ & $\%$ & Tons & $\%$ \\
\hline WTE Program & 95,692 & 612,900 & $2.6 \%$ & 68,800 & $48 \%$ \\
\hline Curbside Recycling Program & 21,498 & $1,591,000$ & $7.2 \%$ & 21,498 & $15 \%$ \\
\hline Yard Waste Program & 16,159 & 874,700 & $3.9 \%$ & 16,159 & $11 \%$ \\
\hline Bulky Waste/Problem Waste & 2,718 & 186,600 & $0.8 \%$ & 2,718 & $1.9 \%$ \\
\hline
\end{tabular}

Note:

A range of costs was calculated in Minneapolis. The mid-point of the range is shown on this table. Discussion of the range of costs is found in the detailed case study.

The following table shows the energy consumed in the collection function. The data is a compilation of information from the city of Minneapolis and Hennepin County, as well as some of the private service providers. Additional energy analyses can be found in the condensed case study.

Table 5. City of Minneapolis - Energy Consumed to Collect Garbage, Yard Waste, Bulky Waste, and Recyclables in the City (FY 1992 Equivalent Diesel Gallons Per Ton)

\begin{tabular}{lcccr}
\hline \multicolumn{1}{c}{ Variables } & Garbage & $\begin{array}{c}\text { Bulky } \\
\text { Waste }\end{array}$ & $\begin{array}{c}\text { Yard } \\
\text { Waste }\end{array}$ & Recyclables \\
\hline City Truck Hours & 41,089 & 6,247 & 9,402 \\
Percent of Truck Hours & 72.42 & 11.01 & 16.57 & 21,499 \\
Tons Collected & 48,355 & 3,220 & 7,823 & 8,648 \\
Millions of Btus & 10,689 & 1,625 & 2,446 & 59,070 \\
Diesel Fuel (Equivalent Gallons) & 73,020 & 11,100 & 16,710 & 2.7 \\
Gallons Per Ton & 1.5 & 3.4 & 2.1 & \\
\hline
\end{tabular}

Sources:

1. City of Minneapolis, "Fuel Use Data," Computer Printouts.

2. Minneapolis Refuse, Inc., "Monthly Invoices," December 30, 1991 through December 31, 1992.

Notes:

a. Data for garbage, yard waste, and bulky waste are from the city only.

b. Data for Recyclables are for both the city and MRI.

c. MRI fuel consumption assumes average price of gasoline and diesel fuel were $\$ 1.10$ and $\$ 1.25$ per gallon,

respectively. (Telephone conversation with Mr. D. Kruell, MRI, October 29, 1994)

d. Conversion to millions of Btus for diesel fuel assumes 146,390 Btus per gallon.

e. Conversion to millions of Btus for gasoline assumes 127,650 Btus per gallon. 
Figure 6. City of Minneapolis (Hennepin County) Total Waste (Tons)

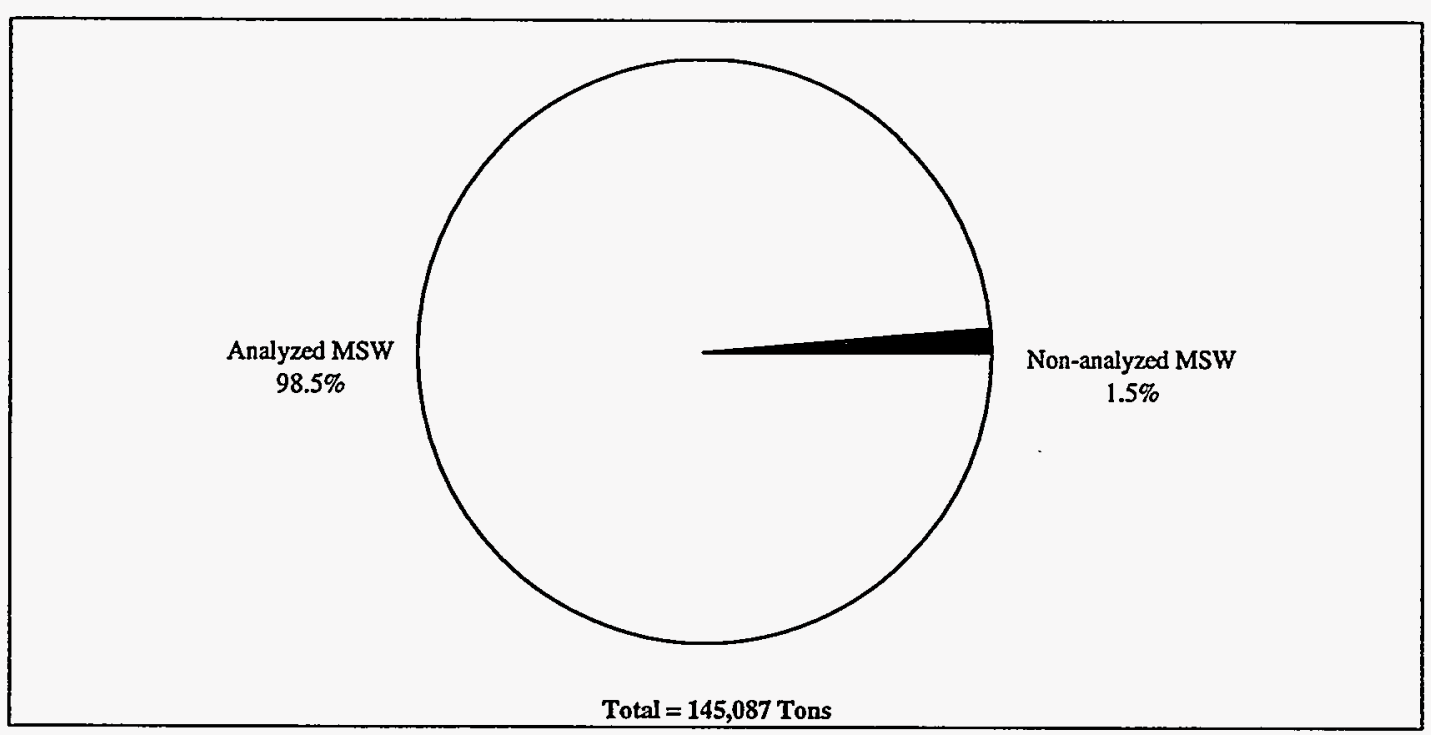

Figure 7. City of Minneapolis Analyzed Waste by Type of Waste (Tons)

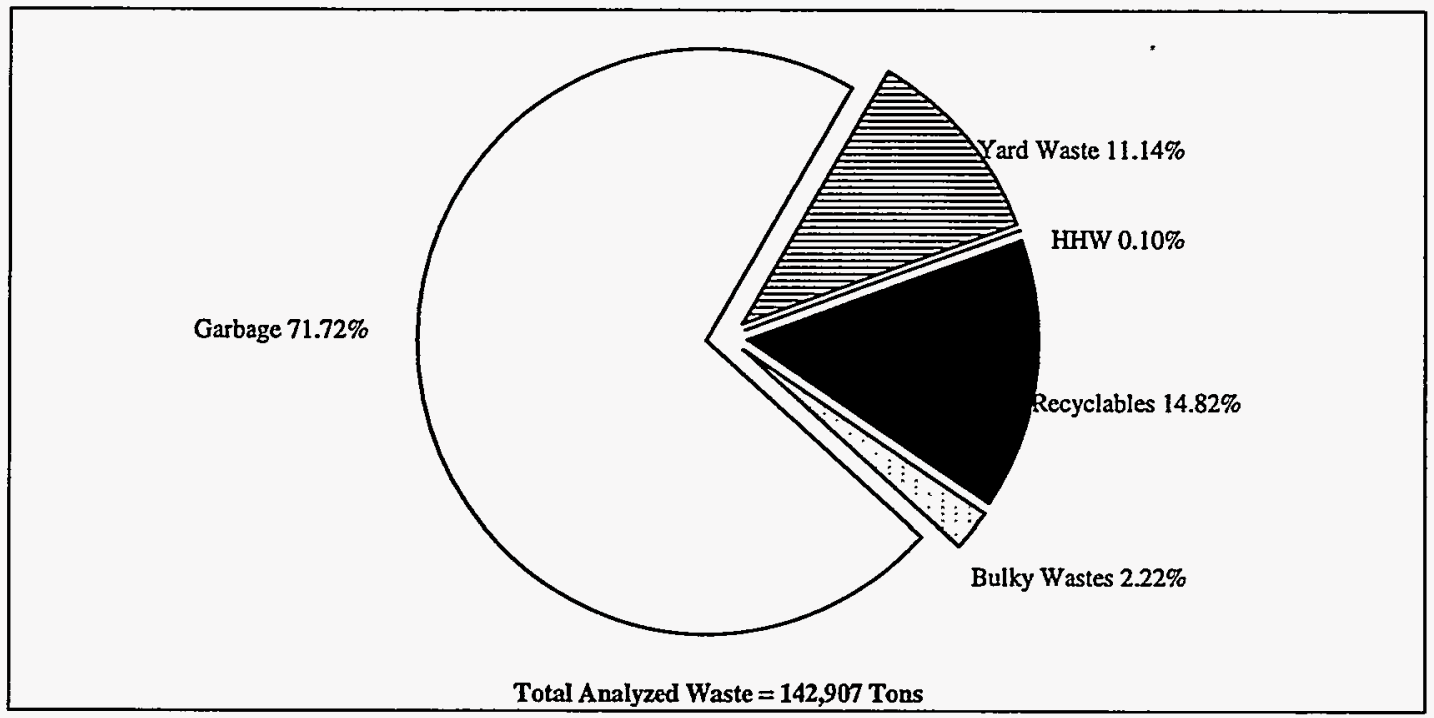


Figure 8. City of Minneapolis Net Costs of Managing Analyzed MSW by Functional Area (FY 1992\$)

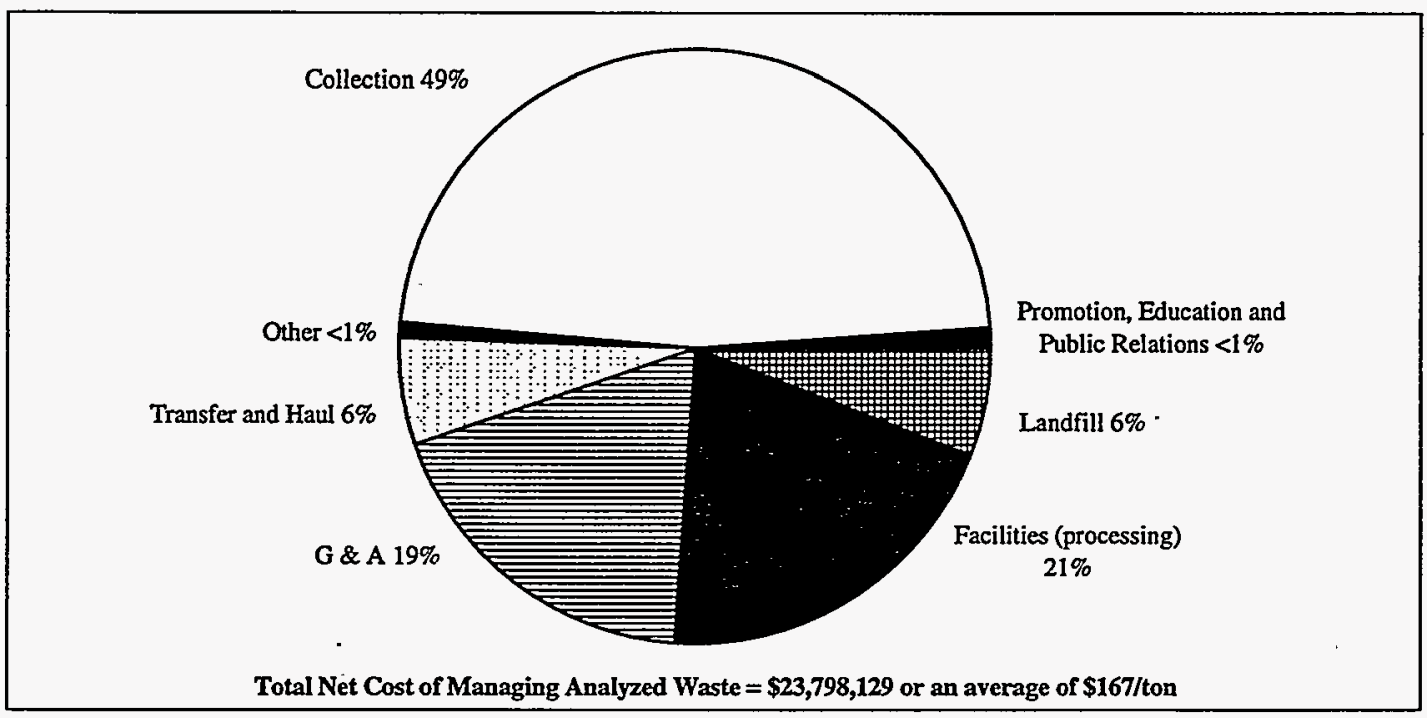

Figure 9. City of Minneapolis Allocation of Net Costs by Type of Waste (FY 1992\$)

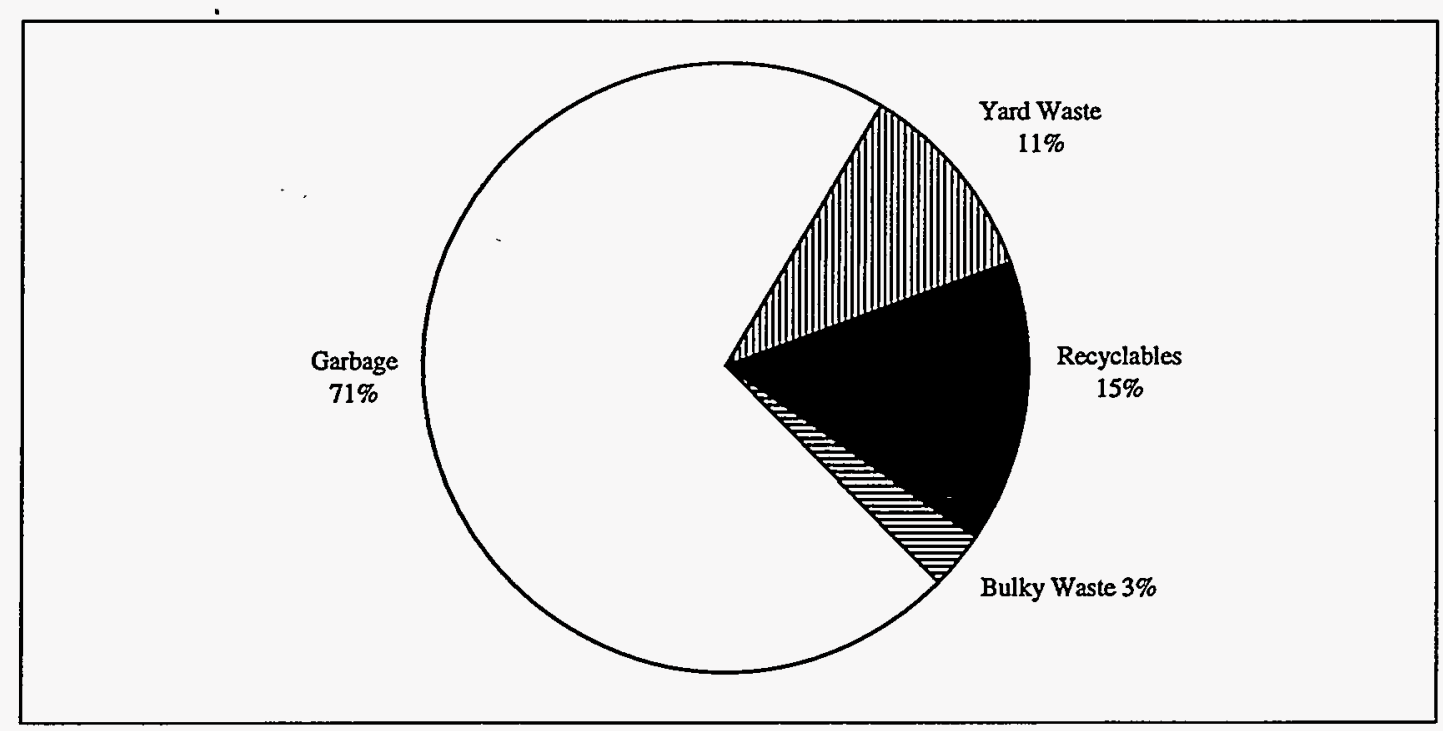


Figure 10. City of Minneapolis Functional Allocation of Net Costs by Type of Waste (FY 1992\$)

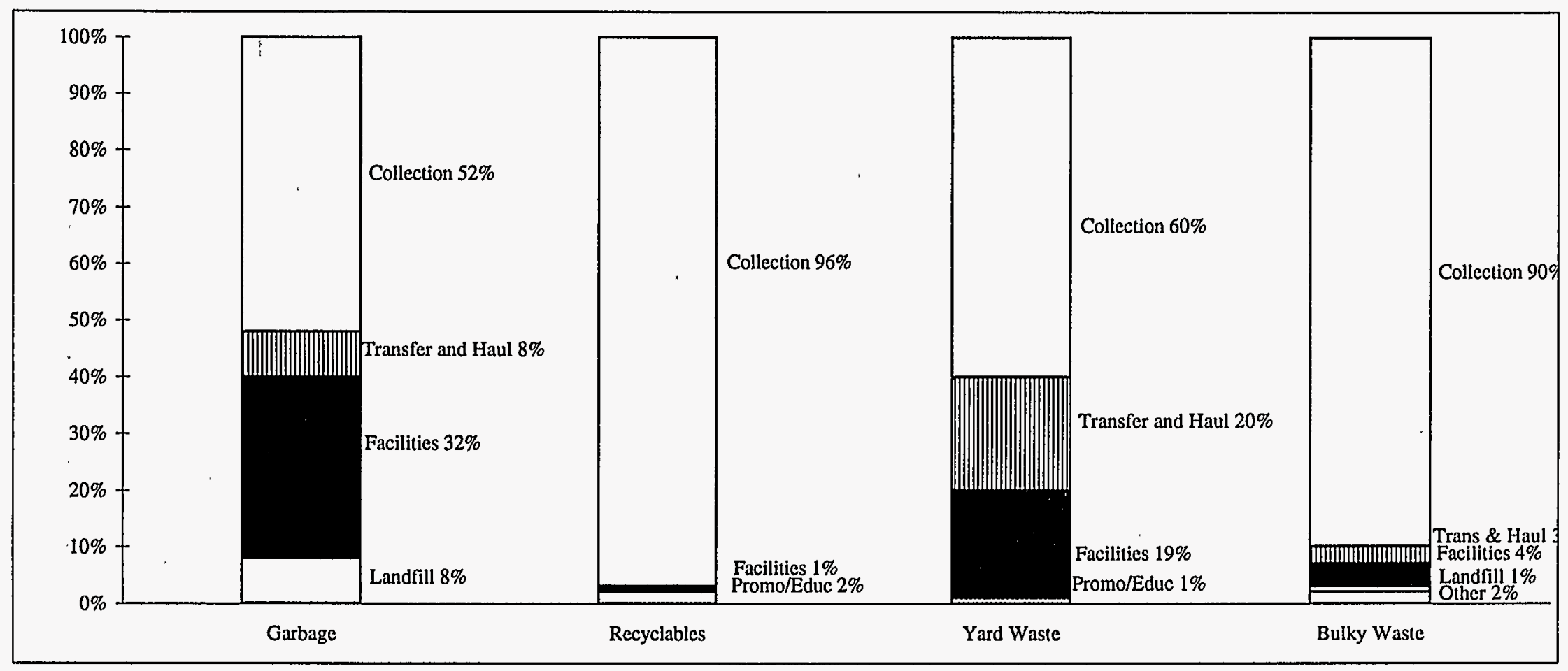




\section{Palm Beach County, Florida}

\section{Economy}

The economic mainstays in this area are real estate and construction industries associated with producing housing for the county's increasing population. Agriculture supports the rural, western area of the county.

\section{Institutional Arrangements}

The Solid Waste Authority of Palm Beach County was created by the state legislature to assume responsibility for the coordinated management of solid waste in the county. The Authority has the power to construct and operate solid waste disposal facilities and to require that all MSW collected by public or private agencies from any municipality or unincorporated area of the county be transported to Authority-designated processing and disposal facilities. The majority of the Authority's revenues come from non ad-valorem assessments charged directly to the owners of residential and commercial property and tip fees from commercial customers.

\section{System Components}

The county's IMSWM system components include curbside garbage, recyclables, yard waste and bulky waste collection service, HHW drop-off sites at the transfer stations, a HHW drop-off and storage facility, and a recyclables drop-off collection program. The system also includes four transfer stations and a WTE facility consisting of an RDF processing facility and an associated combustion facility. Also included in the system components are a ferrous processing facility that produces a marketable product from recovered ferrous, a MRF that processes recyclables, and a co-composting facility that processes sewage sludge mixed with source-separated yard waste. Compost is processed in an enclosed building using an aerated, agitated bay technology. The IMSWM system components also include one Class I landfill, which meets the RCRA Subtitle D requirements, used primarily for disposal of combustion ash and residue and limited amounts of bypass garbage, and one single-lined Class III landfill used primarily for disposal of construction/demolition debris and land-clearing debris.

\section{Results.}

Figures 11, 12, 13, 14 and 15 graphically present the results of the cost of Analyzed MSW management for Palm Beach County.

The average net cost to manage 700,000 tons of Analyzed MSW was $\$ 144$ per ton, in fiscal year 1992 dollars. The following table illustrates the average cost per ton for garbage/trash and recyclables.

Table 6. Palm Beach County - Average Cost/Ton (FY 1992 \$)

\begin{tabular}{lrcc}
\hline \multicolumn{1}{c}{ Category } & Tonnage & Total Costs & Average Cost/Ton \\
\hline Garbage/Trash & 614,000 & $\$ 82$ million & $\$ 134$ \\
Recyclables & 85,800 & $\$ 19$ million & $\$ 218$ \\
Total & $\mathbf{7 0 0 , 0 0 0}$ & $\$ 101$ million & $\$ 144$ \\
\hline
\end{tabular}


The incremental costs (savings) are shown below:

Table 7. Palm Beach County - Program Incremental Costs (Savings) and Diversion

(FY 1992 \$)

\begin{tabular}{|c|c|c|c|c|c|}
\hline & \multirow[t]{2}{*}{$\begin{array}{c}\text { Tons } \\
\text { Managed }\end{array}$} & \multicolumn{2}{|c|}{$\begin{array}{l}\text { Program Incremental } \\
\text { Costs (Savings) }\end{array}$} & \multicolumn{2}{|c|}{$\begin{array}{c}\text { Diversion from } \\
\text { Landfill }\end{array}$} \\
\hline & & $\$$ & $\%$ & Tons & $\%$ \\
\hline $\begin{array}{l}\text { Resource Recovery Facility } \\
\text { Program }\end{array}$ & 437,143 & $\$ 15,3000,000$ & $17.9 \%$ & 265,622 & $38 \%$ \\
\hline $\begin{array}{l}\text { Curbside Collection and MRF } \\
\text { Program }\end{array}$ & 61,585 & $\$ 10,100,000$ & $11.1 \%$ & 61,585 & $9 \%$ \\
\hline
\end{tabular}

The following table shows the energy consumed in the collection function. The data is a compilation of information from the Palm Beach Solid Waste Authority and the municipalities. Additional energy analyses can be found in the condensed case study.

Table 8. Palm Beach County - Energy Consumed to Collect Garbage, Trash and Recyclables (FY 1992 Equivalent Diesel Gallons Per Ton)

\begin{tabular}{lcccc}
\hline \multicolumn{1}{c}{ Variables } & Garbage & \multicolumn{1}{c}{ Trash } & Garbage/Trash & Recyclables \\
\hline Tons Collected & 139,291 & 51,270 & 190,561 & 16,137 \\
$\begin{array}{l}\text { Diesel Fuel Consumed } \\
\text { (gallons) }\end{array}$ & 242,232 & 81,813 & 327,045 & 46,365 \\
Total Miles & & & & \\
Miles Per Gallon & 645,639 & 394,008 & $1,039,647$ & 238,084 \\
Gallons Per Ton & 2.67 & 4.65 & 3.18 & 5.13 \\
\hline
\end{tabular}

Source: Boca Raton, Computer Printouts of Fleet Information and Vehicle Information provided by Waste Management of Palm Beach.

Note: Conversion to millions of Btus assumes 146,390 Btus per gallon. 
Figure 11. Palm Beach County Total Waste (Tons)

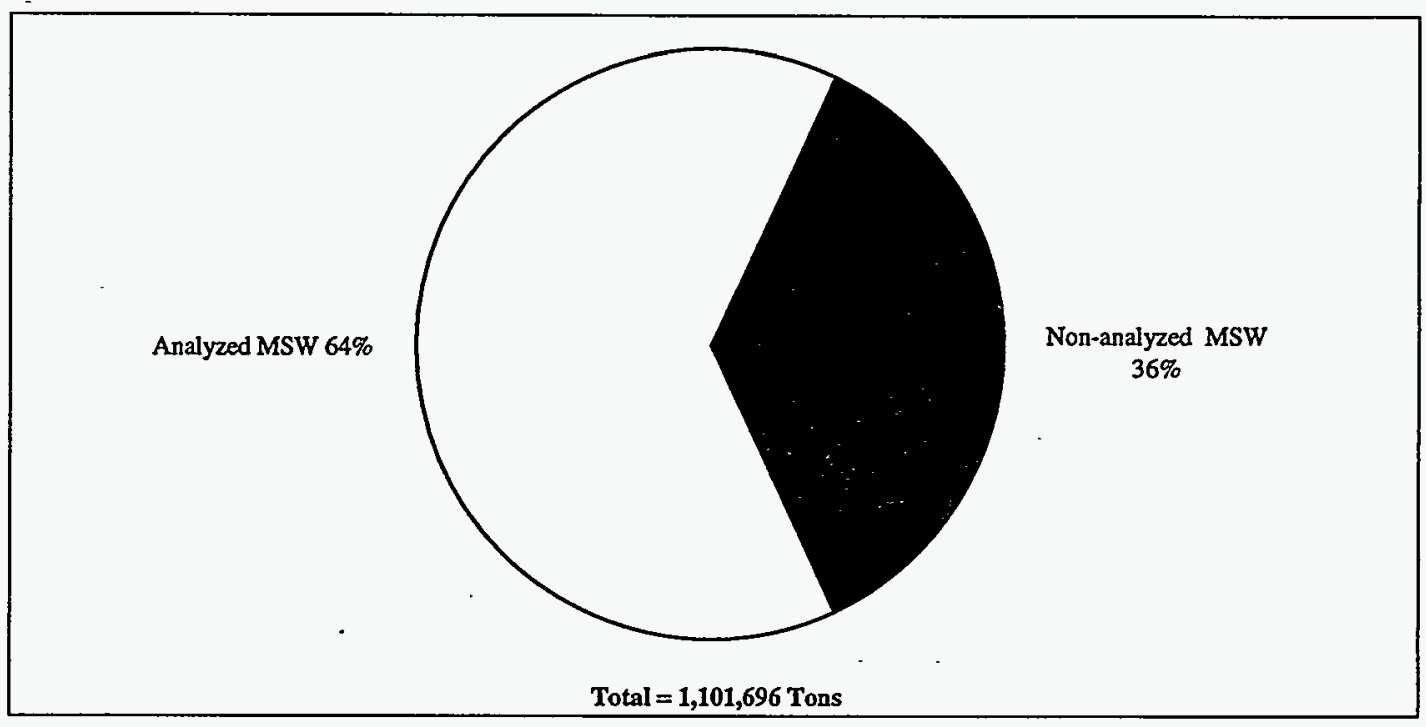

Figure 12. Paim Beach County Analyzed Waste by Type of Waste (Tons)

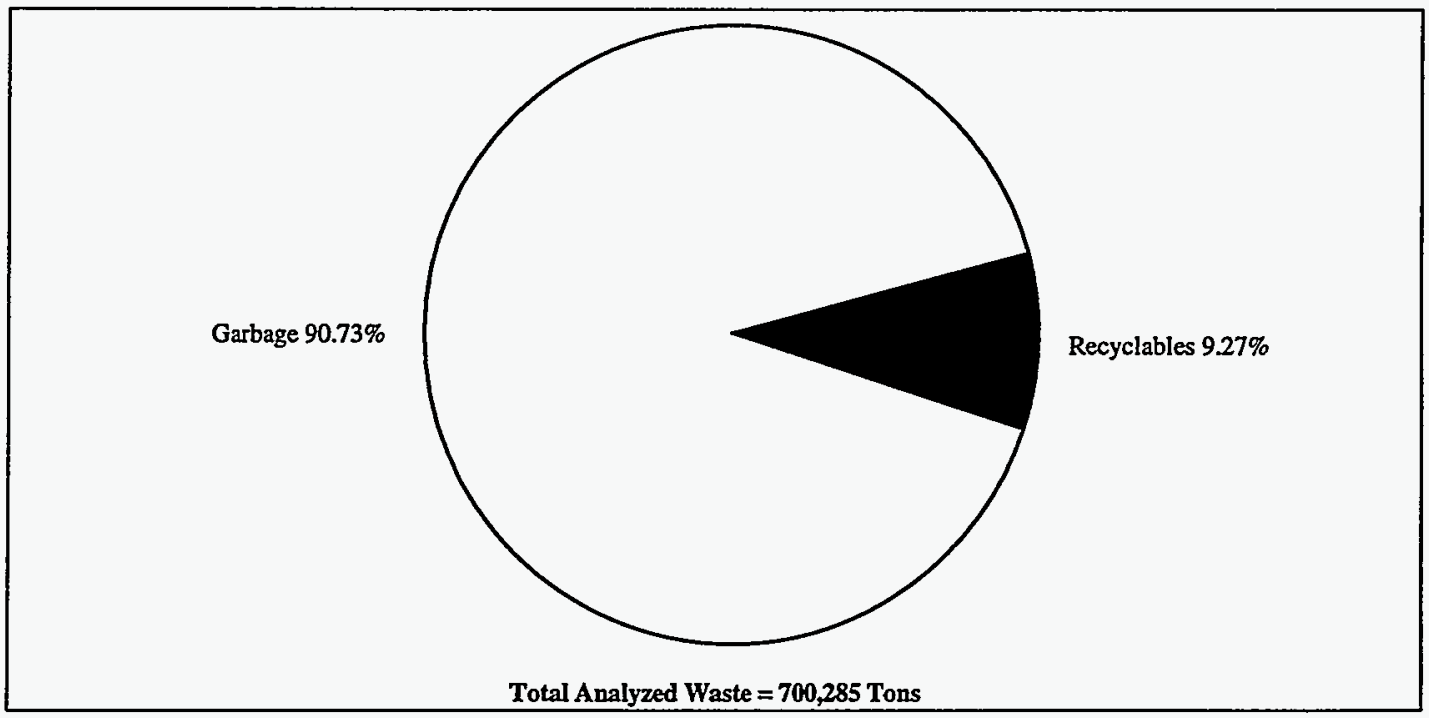


Figure 13. Palm Beach County Net Costs of Managing Analyzed MSW by Functional Area (FY 1992\$)

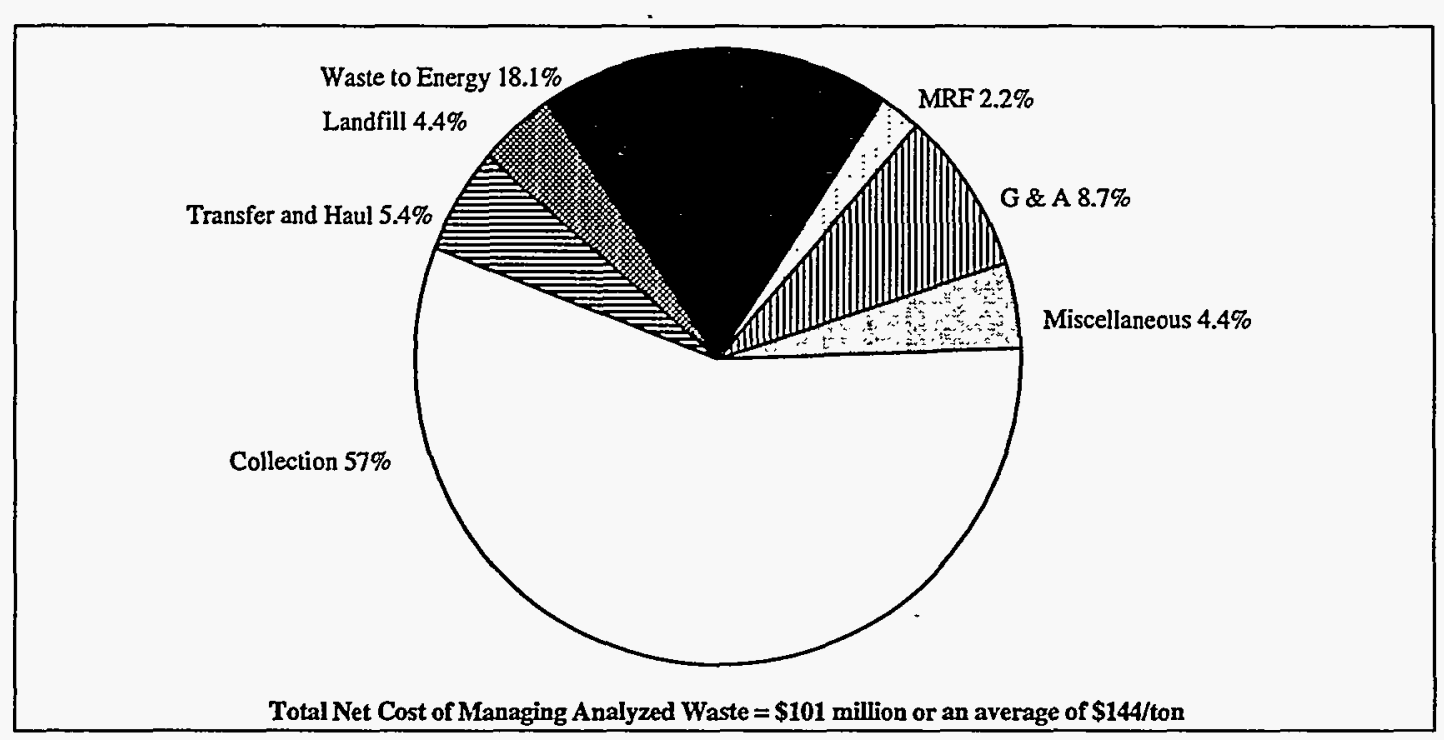

Flgure 14. Palm Beach County Allocation of Total Net Costs by Type of Waste (FY 1992\$)

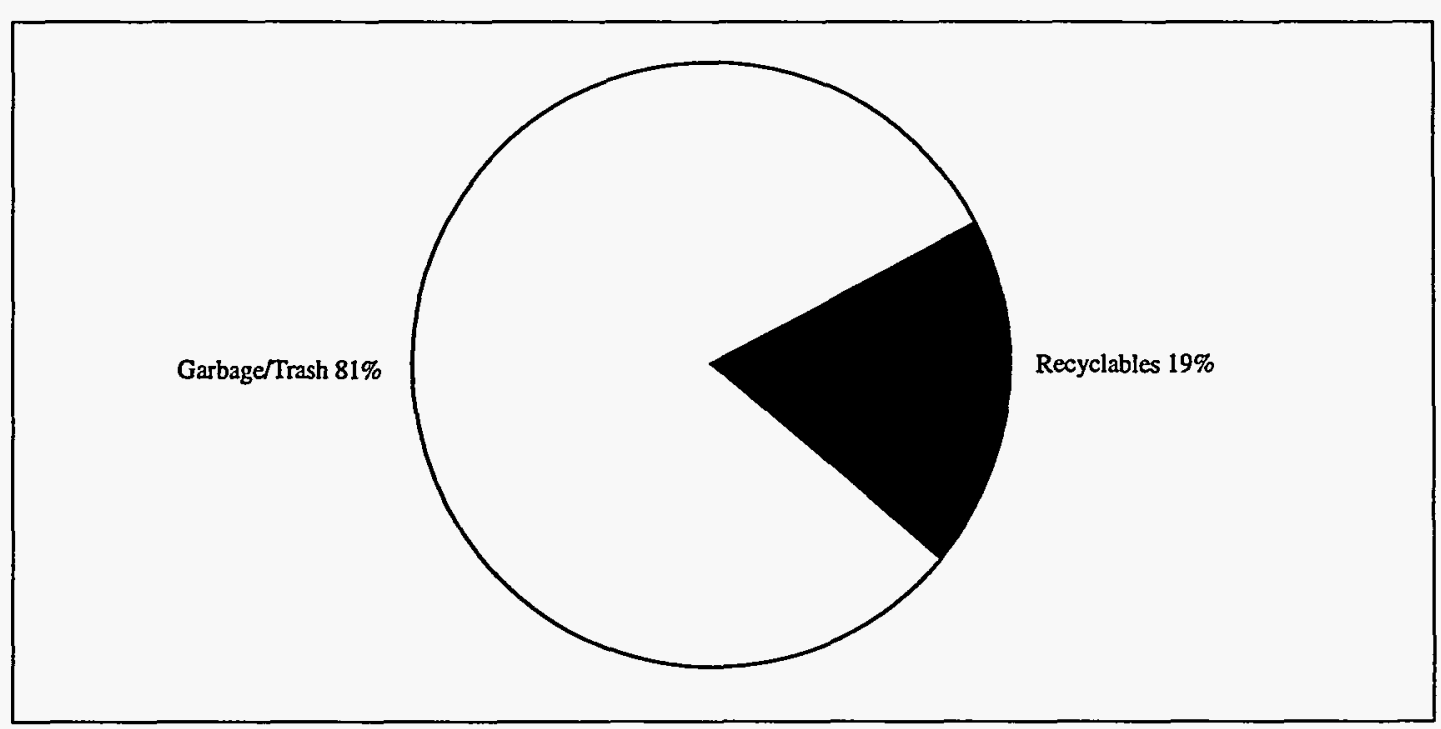




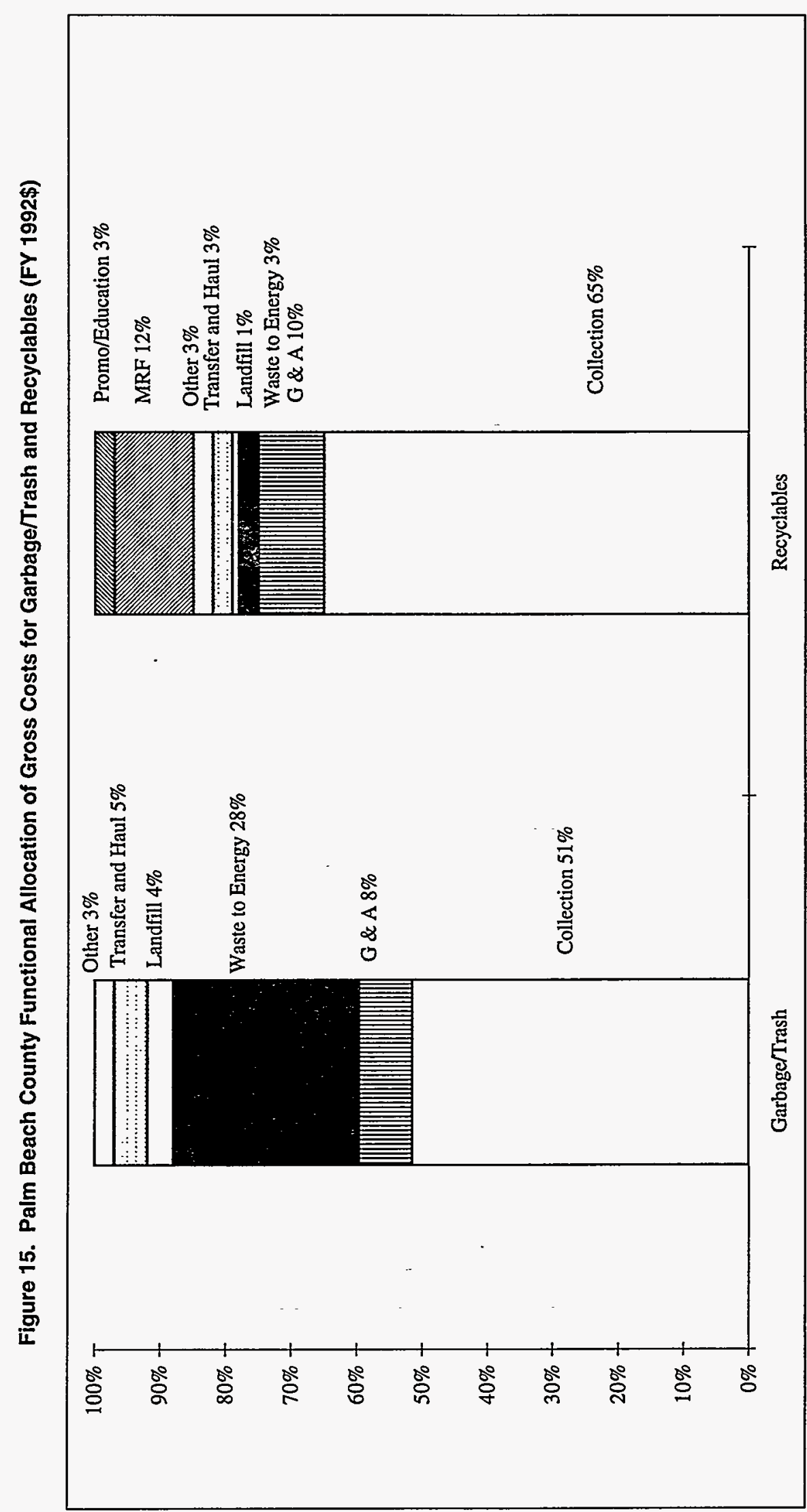




\section{Scottsdale, Arizona}

\section{Economy}

This area has a large amount of undeveloped and agricultural land with only a small amount of industrial or commercial land. Tourism is the city's economic mainstay.

\section{Institutional Arrangements}

The city manages MSW through its Sanitation Division, or the MSW is delivered to the county-owned landfill directly by residents. Household hazardous waste (HHW) is collected by the city and processed by a private contractor.

\section{System Components}

The city's IMSWM system components include curbside garbage, brush/bulky waste, and white goods collection service, including on-call collection of corrugated moving boxes. There are drop-off sites for HHW as well as annual HHW collection days, recyclables drop-off sites, and on-call office paper collection at city buildings. The IMSWM system components also include three unlined landfills for disposal of garbage, brush, and bulky waste.

\section{Results}

Figures 16, 17, 18, 19 and 20 graphically present the results of the cost of Analyzed MSW management for the city of Scottsdale.

The average net cost to manage 112,000 tons of Analyzed MSW was $\$ 59$ per ton, in fiscal year 1992 dollars. The following table illustrates the average cost per ton for each category of waste analyzed.

Table 9. City of Scottsdale - Average Costs Per Ton (FY 1992 \$)

\begin{tabular}{lrcc}
\hline \multicolumn{1}{c}{ Category } & Tonnage & Total Cost & $\begin{array}{c}\text { Average } \\
\text { Cost/Ton }\end{array}$ \\
\hline Residential Garbage & 58,600 & $\$ 3.71$ million & $\$ 63$ \\
Commercial Garbage & 44,800 & $\$ 1.86$ million & $\$ 41$ \\
Brush and Bulky Waste & 7,970 & $\$ 0.86$ million & $\$ 108$ \\
Recyclables & 820 & $\$ 0.15$ million & $\$ 182$ \\
Total & $\mathbf{1 1 2 , 1 9 0}$ & $\$ 6.61$ million & $\$ 59$ \\
\hline
\end{tabular}


The incremental costs (savings) are shown below:

Table 10. City of Scottsdale - Program Incremental Costs (Savings) and Diversion (FY 1992 \$)

\begin{tabular}{lccc|cc}
\hline & $\begin{array}{c}\text { Tons } \\
\text { Managed }\end{array}$ & \multicolumn{2}{c}{$\begin{array}{c}\text { Program } \\
\text { Incremental } \\
\text { Costs (Savings) }\end{array}$} & \multicolumn{2}{c}{$\begin{array}{c}\text { Diversion from } \\
\text { Landfill }\end{array}$} \\
\cline { 3 - 7 } & & $\$$ & $\%$ & Tons & $\%$ \\
\hline Mobile Recycling Program & 401 & 69,373 & $1.05 \%$ & 401 & $0.4 \%$ \\
Office Waste Paper Recycling Program & 30 & $(900)$ & 0 & 30 & 0 \\
Move-in Boxes Recycling Program & 58 & 522 & 0 & 58 & 0 \\
White Goods Recycling Program & 55 & 495 & 0 & 55 & 0 \\
Stationary Container Program & 279 & 2,511 & 0 & 279 & $0.25 \%$ \\
\hline
\end{tabular}

The following table shows the energy consumed to manage garbage, brush and recyclables. Additional energy analyses can be found in the condensed case study.

Table 11. City of Scottsdale - Energy Consumed to Manage Garbage Brush, and Recyclables (FY 1992 Equivalent Diesel Gallons Per Ton)

\begin{tabular}{lcccc}
\hline \multicolumn{1}{c}{ Activity } & $\begin{array}{c}\text { Residential } \\
\text { Garbage }\end{array}$ & $\begin{array}{c}\text { Commercial } \\
\text { Garbage }\end{array}$ & Brush & Recyclables \\
\hline Sanitation Collection Vehicles & 2.1 & 1.3 & 2.2 & 2.9 \\
$\begin{array}{l}\text { Individual Cars and Trucks } \\
\text { Container Repair \& Misc. Fleet }\end{array}$ & $<0.1$ & $<0.1$ & $<0.1$ & 4.2 \\
Landfills & 0.4 & 0.4 & 0.4 & $<0.1$ \\
Total Fuel Equivalent (gallons/ton) & 2.5 & 1.8 & 2.7 & $\mathbf{7 . 2}$ \\
Total Fuel Equivalent (Btu/ton) & $\mathbf{3 7 0 , 0 0 0}$ & $\mathbf{2 5 6 , 5 0 0}$ & $\mathbf{3 9 0 , 2 0 0}$ & $\mathbf{1 , 0 4 9 , 6 0 0}$ \\
\hline $\begin{array}{l}\text { Notes: } \\
\text { a. Gallons are expressed as equivalent (on Btu basis) gallons of diesel fuel. }\end{array}$ & & & \\
b. Btu content of diesel fuel is 146,390 Btu per gallon. \\
c. Based on 58,568, 44,775, 7,868,793 tons of residential garbage, commercial garbage, brush, and recyclables, respectively.
\end{tabular}


Figure 16. City of Scottsdale Total Waste (Tons)

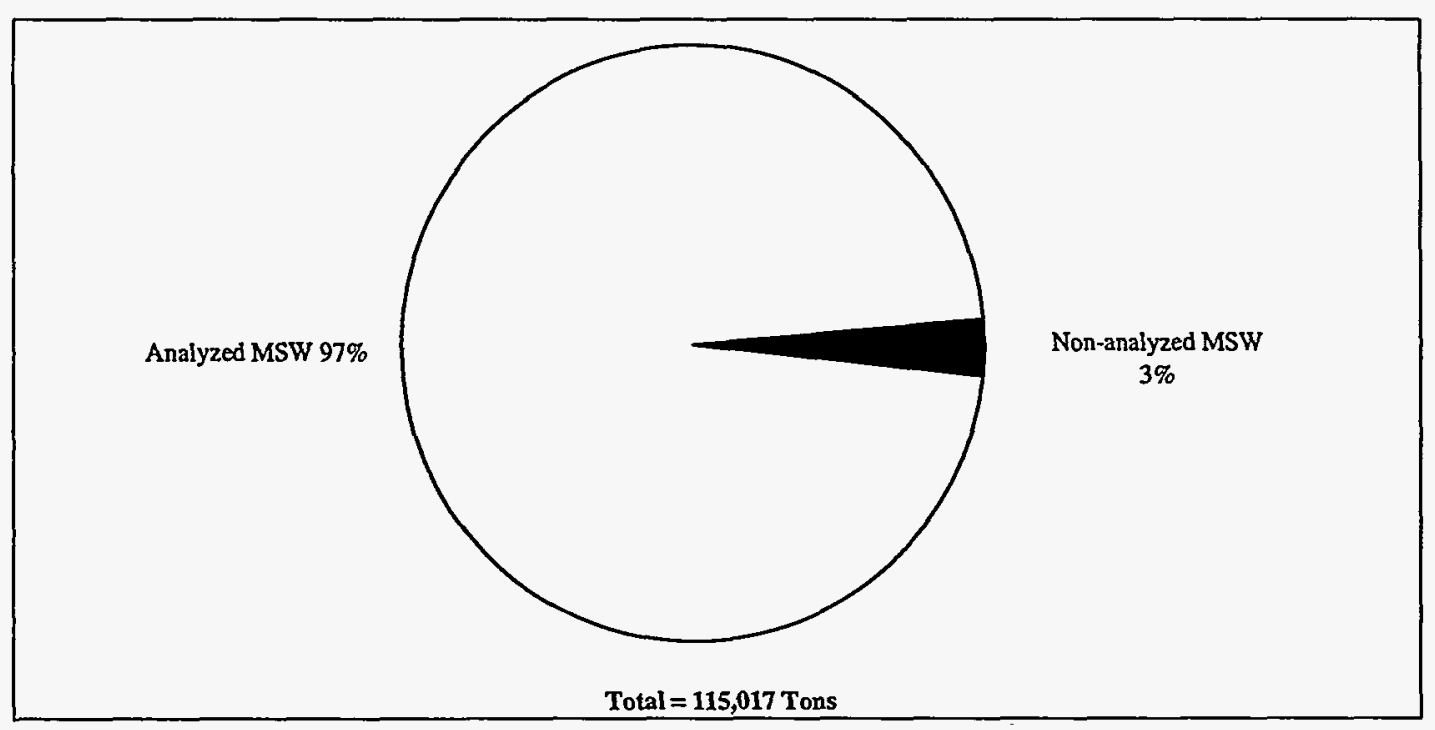

Figure 17. City of Scottsdale Analyzed Waste by Type of Waste

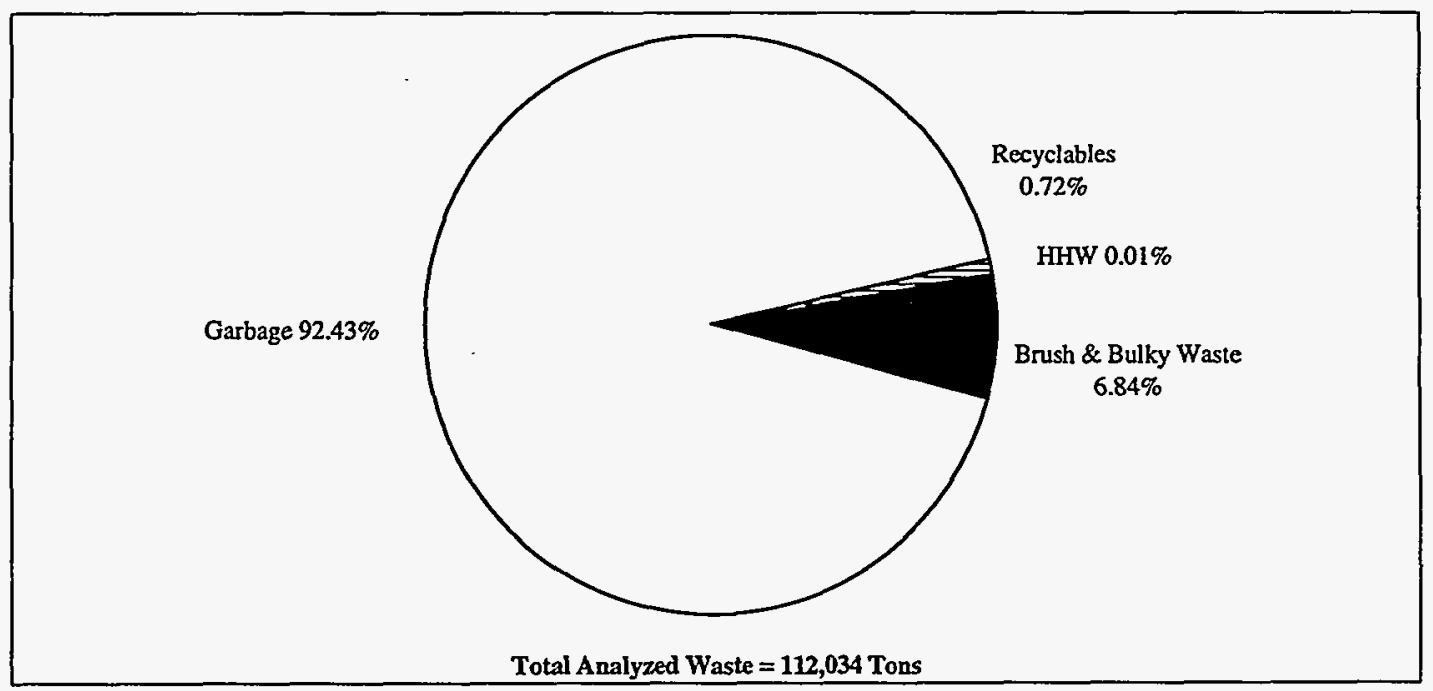


Figure 18. City of Scottsdale Net Costs of Managing Analyzed MSW by Functional Area (FY 1993\$)

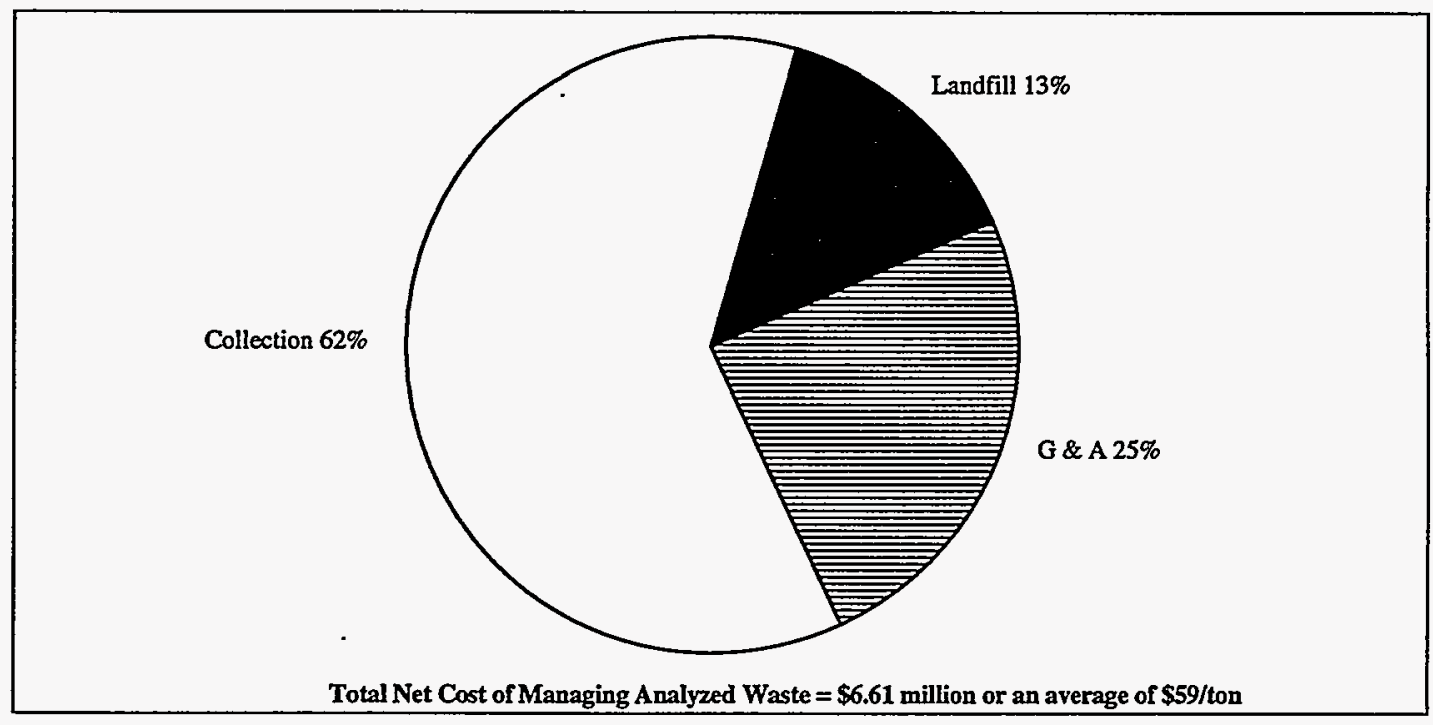

Figure 19. City of Scottsdale Allocation of Net Costs by Type of Waste (FY 1992\$)

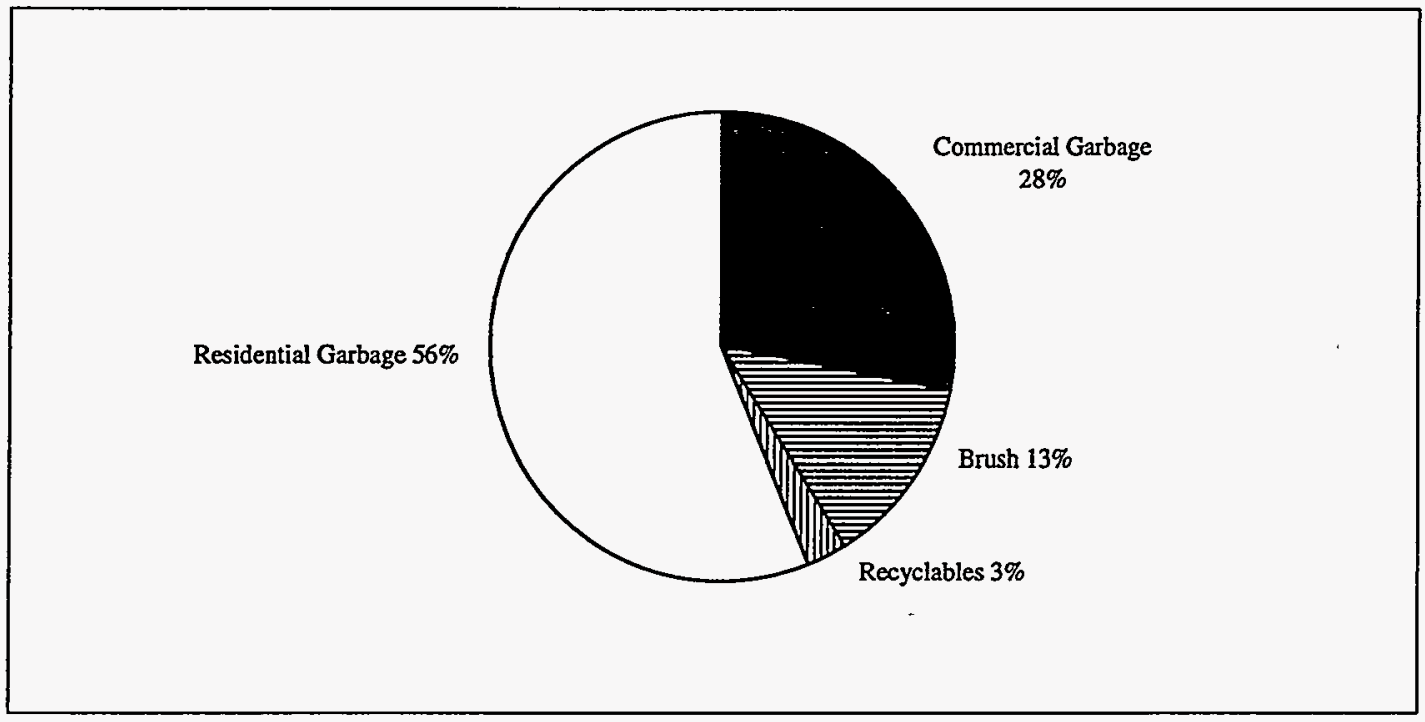




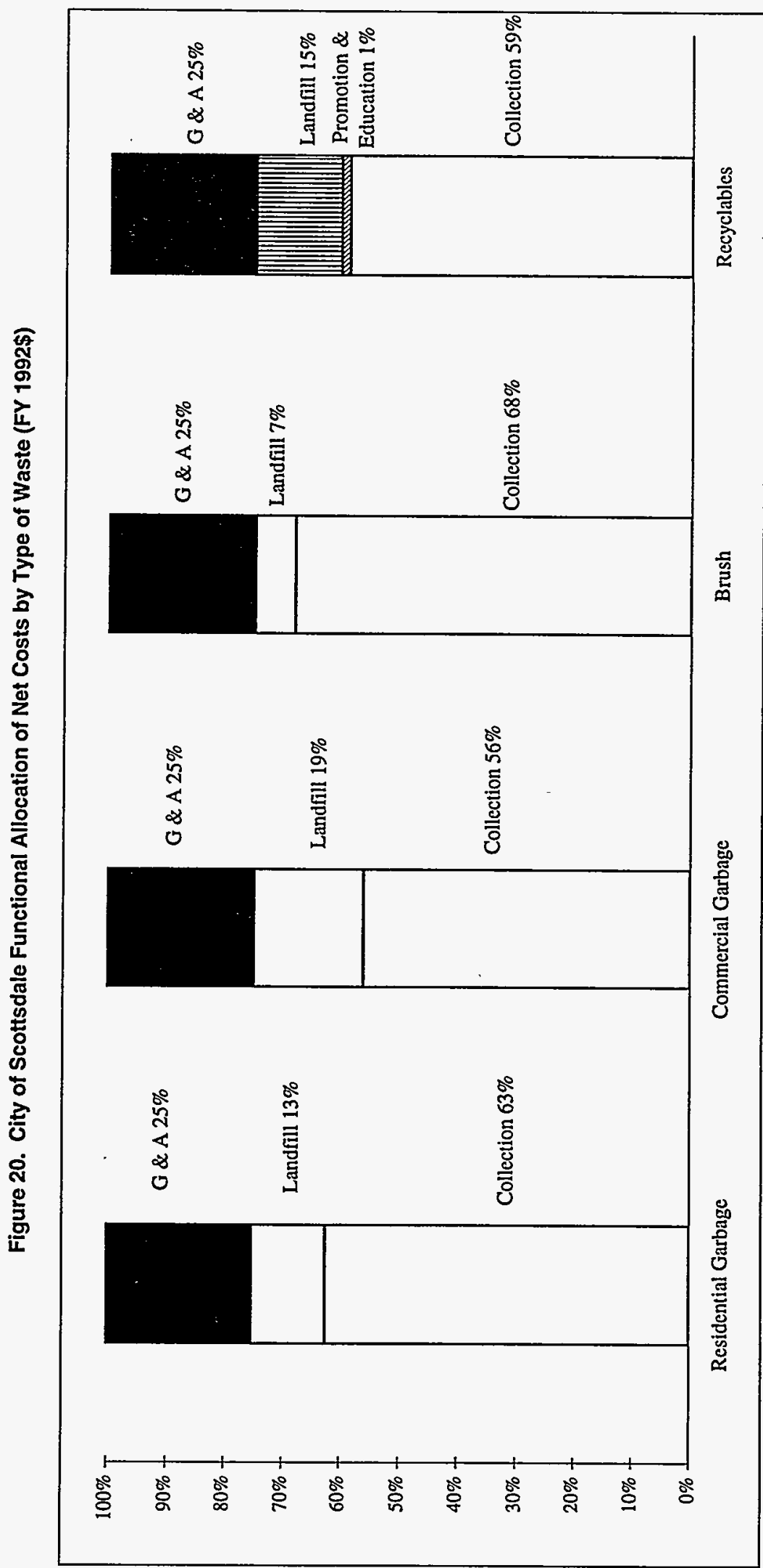




\section{Economy}

The aircraft industry is the economic mainstay of this area with ship building and wood products manufacturing as other major industries. Also, the city has long been a major port of trade to Asia and the principal gateway to Alaska.

\section{Institutional Arrangements}

Seattle manages the collection and disposal of MSW through the Seattle Solid Waste Utility, which provides direct MSW management services, procures other solid waste management services, and manages the IMSWM system. The utility operates as an independent financial entity that must be self-supporting (it cannot receive subsidies from general funds or tax revenues). The utility charges variable or volume-based fees to cover its costs. The utility controls the disposition of residential and commercial solid waste generated within the city, exclusive of "materials destined for recycling," pursuant to a 1991 Seattle flow control ordinance.

\section{System Components}

The city's IMSWM system components include curbside garbage, recyclables, and yard waste collection service, an on-call white goods collection service, and drop-off sites for yard waste, recyclables, HHW, and used oil. The HHW is dropped off at a HHW drop-off and processing facility. The system components also include two transfer stations, two MRFs, and a source-separated yard waste compost facility. The compost facility is in a rural area and is an open air facility, using large windrow piles, which are turned and aerated by a windrow turner, to process the compost. The IMSWM components also include one lined landfill located in Oregon. The MSW is hauled via rail for disposal in the landfill.

\section{Results}

Figures 21, 22, 23, 24 and 25 graphically present the results of the cost analysis of Analyzed MSW management for the city of Seattle.

In Seattle, less than half of the total MSW waste stream was analyzed because costs could not be determined for self-hauled MSW and recyclables primarily from the commercial sector. The average total cost to manage 232,000 tons of Analyzed MSW was $\$ 130$ per ton, in fiscal year 1992 dollars. The following table illustrates the average cost per ton for each category of waste analyzed. 
Table 12. City of Seattle - Average Costs Per Ton (FY $1992 \$$ )

\begin{tabular}{lccr}
\hline Category & Tonnage & Total Cost & Average Cost/Ton \\
\hline Garbage & 142,000 & $\$ 21.6$ million & $\$ 152$ \\
Recyclables & 54,600 & $\$ 4.5$ million & $\$ 88$ \\
& $(51,100$ recycled) & & (per ton recycled) \\
Yard Waste & 34,790 & $\$ 4.1$ million & $\$ 119$ \\
& $(34,440$ sold) & & (per ton sold) \\
Total & $\mathbf{2 3 2 , 0 0 0}$ & $\mathbf{\$ 3 0 . 2}$ million & $\$ \mathbf{1 3 0}$ \\
\hline
\end{tabular}

The incremental costs (savings) are shown below:

Table 13. City of Seattle - Program Incremental Costs (Savings) and Diversion (FY 1992 \$)

\begin{tabular}{llcc|cc} 
& \multirow{2}{*}{$\begin{array}{l}\text { Tons } \\
\text { Managed }\end{array}$} & \multicolumn{2}{c}{$\begin{array}{c}\text { Incremental Cost } \\
\text { (Savings) }\end{array}$} & \multicolumn{2}{c}{$\begin{array}{c}\text { Diversion from } \\
\text { Landfill }\end{array}$} \\
\cline { 4 - 7 } & & $\$$ & $\%$ & Tons & $\%$ \\
\hline Curbside Recycling Program & 48,200 & $(17,200)$ & $-0.1 \%$ & 48,200 & 21 \\
Yard Waste Composting & 45,500 & 568,000 & $1.9 \%$ & 45,500 & 20 \\
\hline
\end{tabular}

Data on energy consumption for the Seattle IMSWM system were available only on the Recycle America Materials Recovery Facility. Analysis of that data indicated that, on an equivalent gallons of diesel fuel per ton basis, the energy consumption with the curbside recycling program in FY 1992 was:

\begin{tabular}{lr} 
Activity & Gallons/Ton \\
\hline Collection of Recyclables & 3.6 \\
Processing of Recyclables & 0.3 \\
Total & 3.9 \\
\hline
\end{tabular}


Figure 21. City of Seattle Total Waste (Tons)

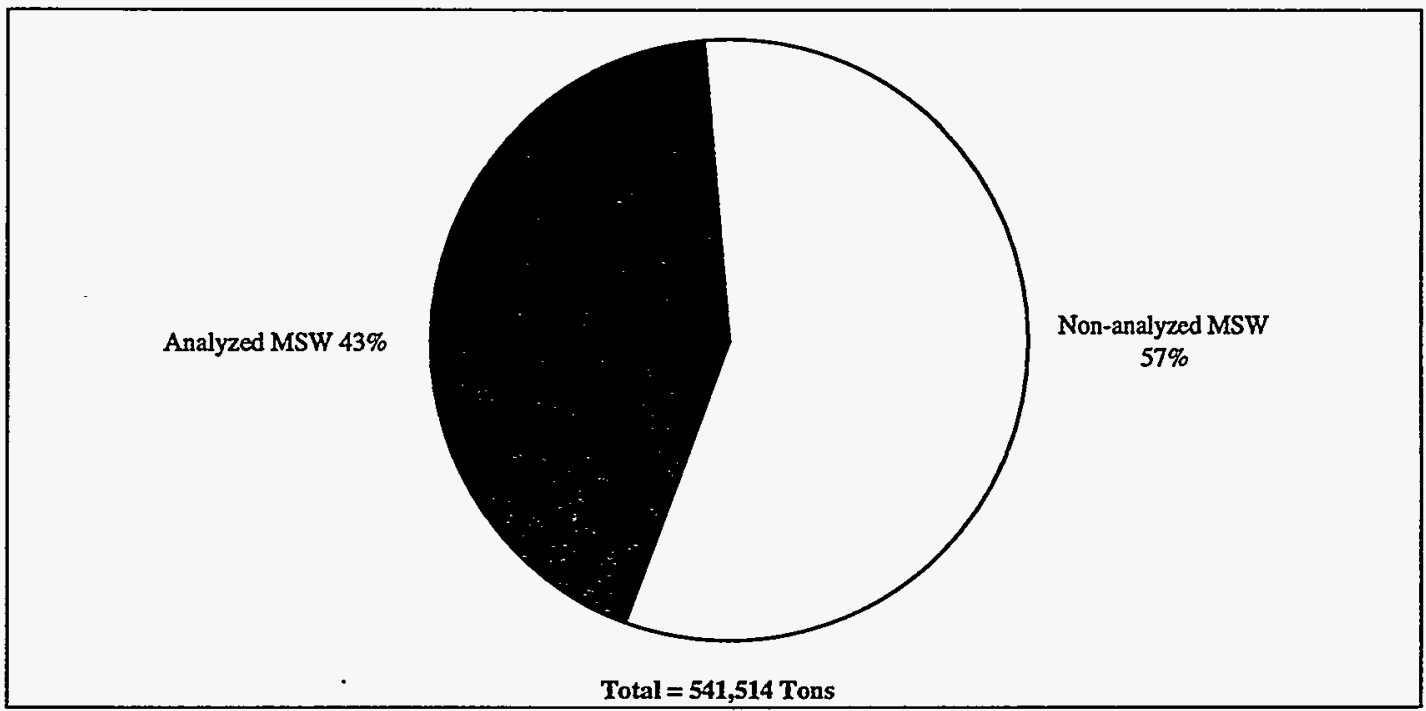

Figure 22. City of Seattle Analyzed Waste by Type of Waste (Tons)

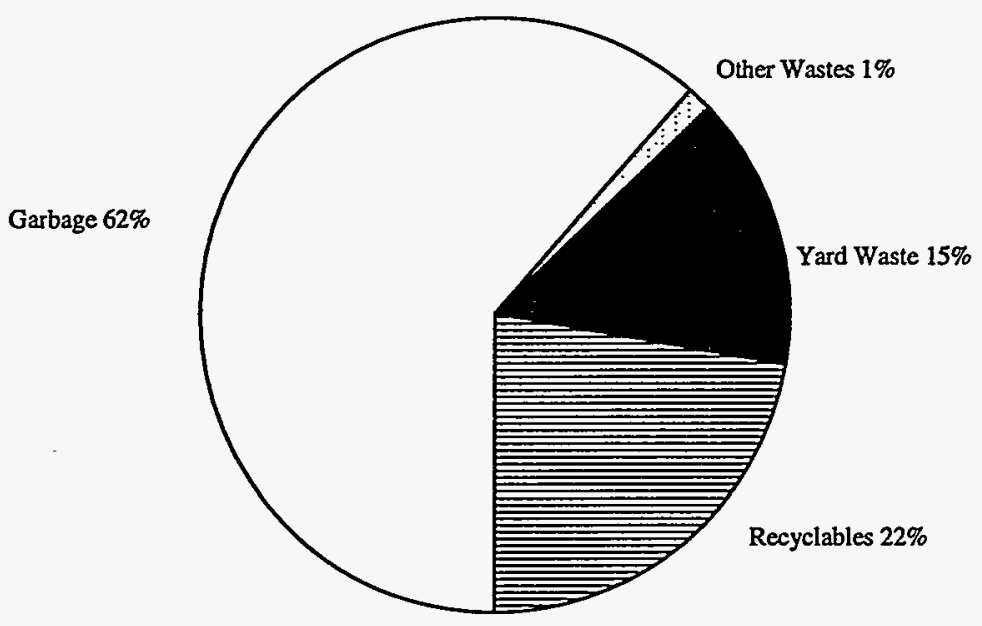

Total Analyzed Waste $=231,544$ Tons 
Figure 23. City of Seattle Net Costs of Managing Analyzed MSW by Functional Area (FY 1992\$)

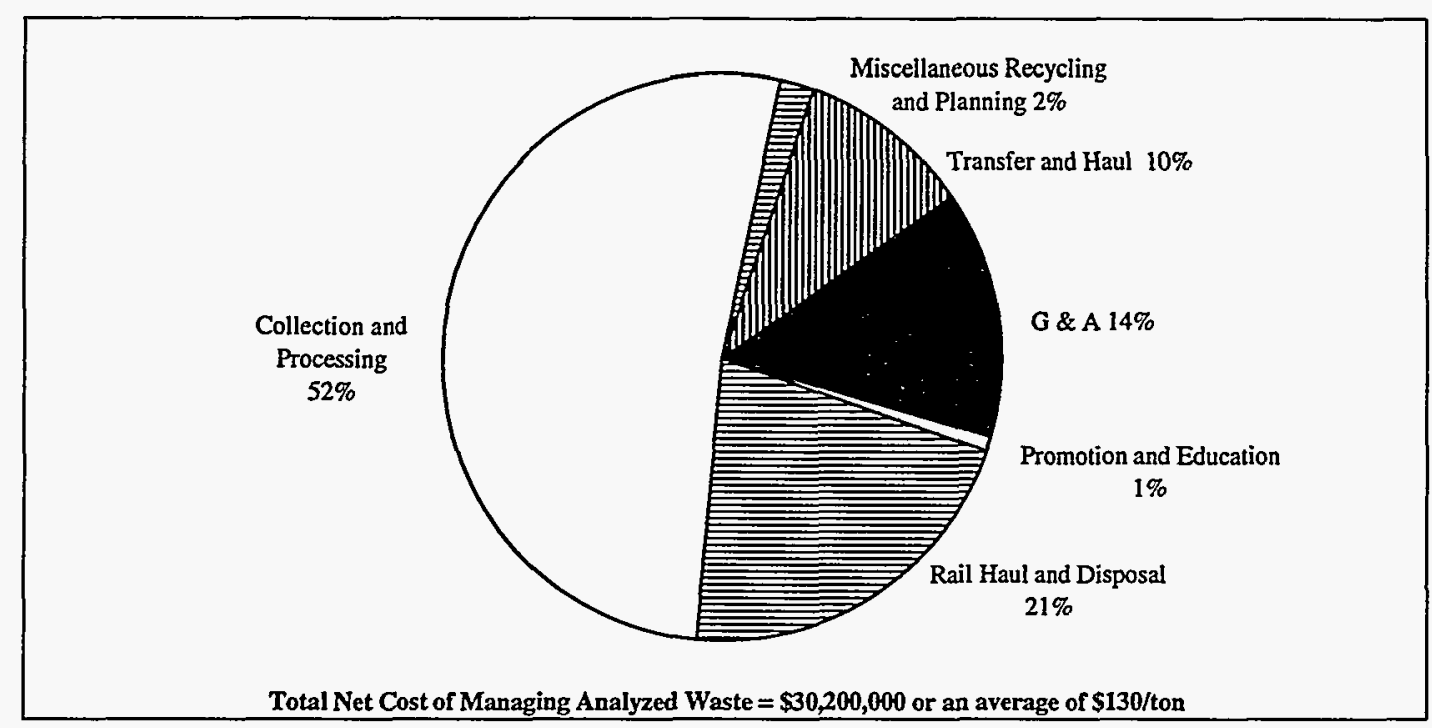

Figure 24. City of Seattle Allocation of Net Costs by Type of Waste (FY 1992\$)

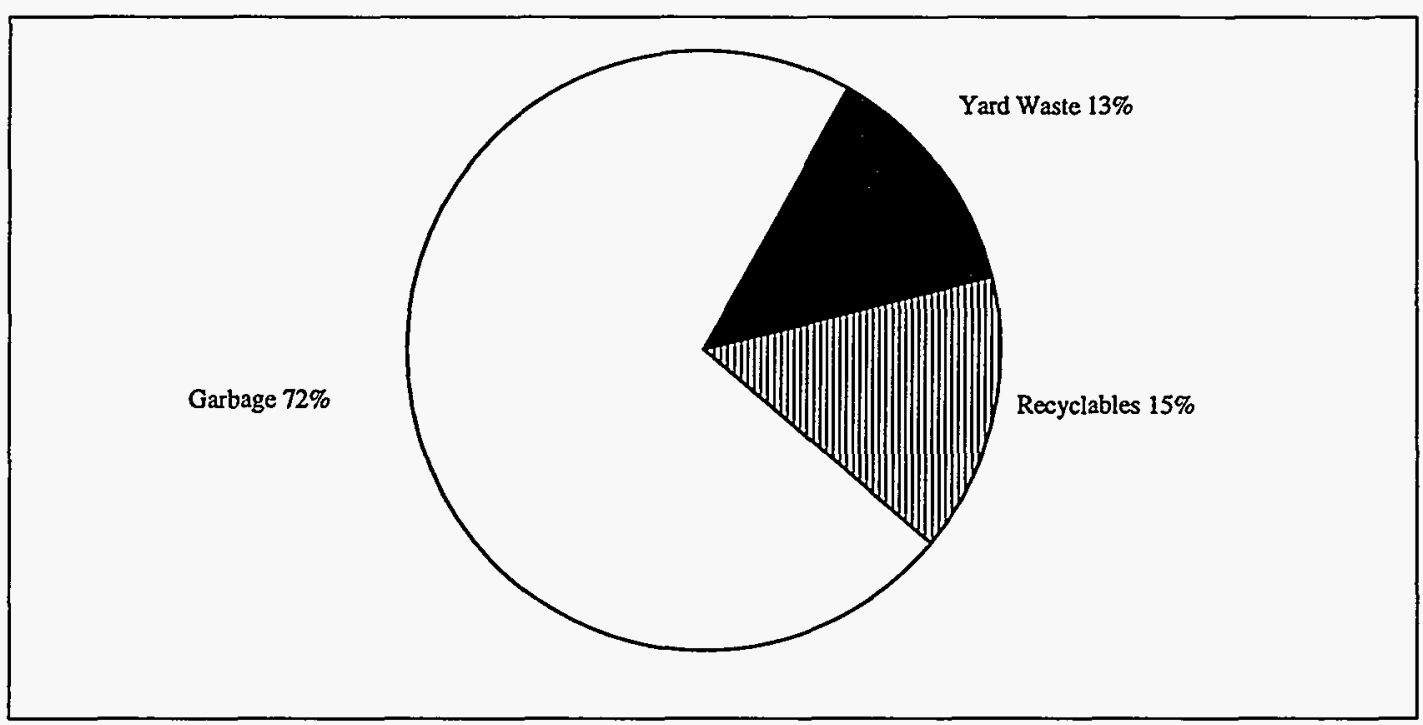


Figure 25. City of Seattle Functional Allocation of Net Costs by Type of Waste (FY 1992\$)

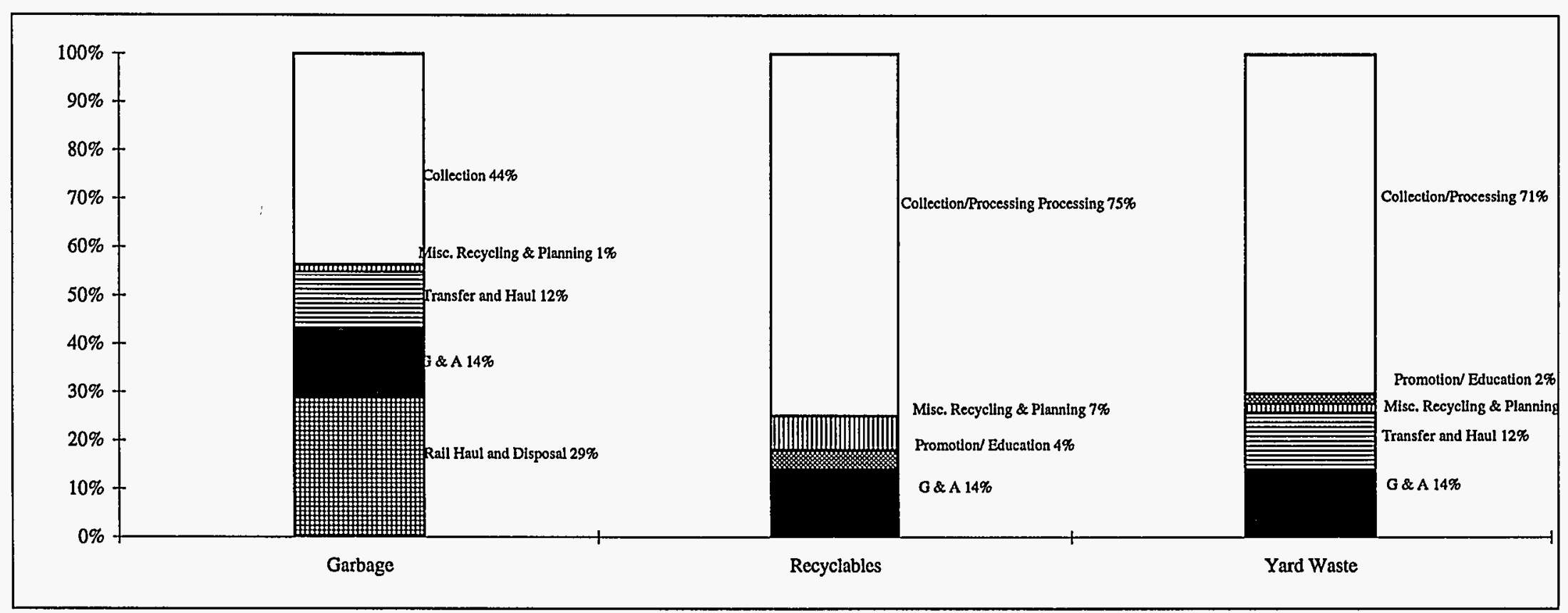




\section{Economy}

Tourism drives the economy of this area, but it also has an industrial park with several industries.

\section{Institutional Arrangements}

Sevierville is located in Sevier County, Tennessee, and is the county seat. In December 1988, Sevier Solid Waste, Inc. (SSWI), a not-for-profit corporation, was formed as an intergovernmental venture between the county and three of the four cities in the county to address solid waste management in the county. SSWI owns the MSW facilities currently serving the entire county. Respective quantities of waste managed in the SSWI facilities are used to determine the relative amount paid by each government entity for use of the SSWI facilities.

\section{System Components}

The city's IMSWM system components include curbside garbage and bulky waste collection, commercial corrugated collection, and drop-off sites for recyclables and used motor oil. There is a corrugated processing and baling facility, and a co-composting facility that processes mixed MSW, sewage sludge, and grease using rotating drum digesters. The facility also employs manual and mechanical screening and aerated bays. The system components also includes two landfills. The Class I landfill, which meets RCRA Subtitle D requirements, is used for disposal of primarily residue, along with some bypass waste from the compost facility. The unlined Class IV landfill is used for disposal of construction and demolition debris and bulky waste. Metals, white goods, wood waste and tires are recovered at the Class IV landfill.

\section{Results}

Figures 26, 27, 28, 29 and 30 graphically present the results of the cost analysis of Analyzed MSW management for the city of Sevierville. The average net cost to manage 10,300 tons of Analyzed MSW was $\$ 106$ per ton, in fiscal year 1992 dollars. The following table illustrates the average cost per ton for each category of waste analyzed.

Table 14. City of Sevierville - Average Costs Per Ton (FY 1993/94 \$)

\begin{tabular}{lrcc}
\hline Category & Tonnage & Total Cost & Total Cost/Ton \\
\hline Garbage & 10,280 & $\$ 1.076$ million & $\$ 105$ \\
Corrugated & 31 & $\$ 16,560$ & $\$ 534$ \\
TotaVAverage & $\mathbf{1 0 , 3 1 1}$ & $\$ 1.092$ million & $\$ 106$ \\
\hline
\end{tabular}

The incremental costs (savings) are shown below: 
Table 15. City of Sevierville - Program Incremental Costs (Savings) and Diversion

(FY 1993/94 \$)

\begin{tabular}{lccc|ccc}
\hline & \multirow{2}{*}{$\begin{array}{c}\text { Tons } \\
\text { Managed }\end{array}$} & \multicolumn{2}{c}{$\begin{array}{c}\text { Program Incremental } \\
\text { Costs }\end{array}$} & \multicolumn{2}{c}{$\begin{array}{c}\text { Diversion from } \\
\text { Landfill }\end{array}$} \\
\cline { 3 - 7 } & & $\$$ & Tons & $\%$ \\
\hline OCC Recovery Program & 31 & 14,750 & $1.4 \%$ & 31 & $0.3 \%$ \\
Composting Pacility & 10,280 & 221,680 & $25.5 \%$ & 7,082 & $69 \%$ \\
\hline
\end{tabular}

Table 16 summarizes the results of the energy analyses performed in the Sevierville case study.

Table 16. City of Sevierville - Energy Consumed for Managing Analyzed MSW

(FY 1993/94 Equivalent Diesel Gallons Per Ton)

\begin{tabular}{|c|c|c|c|}
\hline \multirow[t]{2}{*}{ Activity } & \multicolumn{3}{|c|}{ Equivalent Diesel Gallons Per Ton } \\
\hline & Garbage & $\begin{array}{l}\text { Commercial } \\
\text { Corrugated } \\
\end{array}$ & Total Analyzed MSW \\
\hline \multicolumn{4}{|l|}{ Collection Vehicles } \\
\hline Garbage & 1.75 & NA & 1.75 \\
\hline Corrugated & NA & 7.38 & 0.02 \\
\hline Subtotal & 1.75 & 7.38 & 1.77 \\
\hline \multicolumn{4}{|l|}{ Facilities } \\
\hline Recycling Warehouse & N/A & 4.41 & 0.01 \\
\hline Composting Facility & 2.53 & N/A & 2.52 \\
\hline Class I Landfill & 0.17 & $\mathrm{~N} / \mathrm{A}$ & 0.17 \\
\hline Subtotal & 2.70 & 4.41 & 2.70 \\
\hline \multicolumn{4}{|l|}{ Haul to Markets ${ }^{[b]}$} \\
\hline Compost & 0.08 & N/A & 0.08 \\
\hline Corrugated & N/A & 2.20 & 0.01 \\
\hline Ferrous & 0.02 & N/A & 0.02 \\
\hline Subtotal & 0.10 & 2.20 & 0.11 \\
\hline Total & 4.55 & 13.99 & 4.58 \\
\hline
\end{tabular}


Notes:

[a] Energy content of diesel fuel assumed to be 146,390 Btus/gallon. Quantity of garbage in Analyzed MSW is 10,280 tons. Quantity of commercial OCC in Analyzed MSW is 31 tons.

[b] Includes energy consumed to haul materials to first destination after leaving Sevier Solid Waste Incorporated site. For compost and OCC, the first destination is the end-user/remanufacturer. This destination for ferrous is an intermediate processor. Data on energy consumption at the intermediate processing facility and energy consumed while hauling the ferrous to a remanufacturer was not available. 
Figure 26. City of Sevierville Total Waste (Tons)

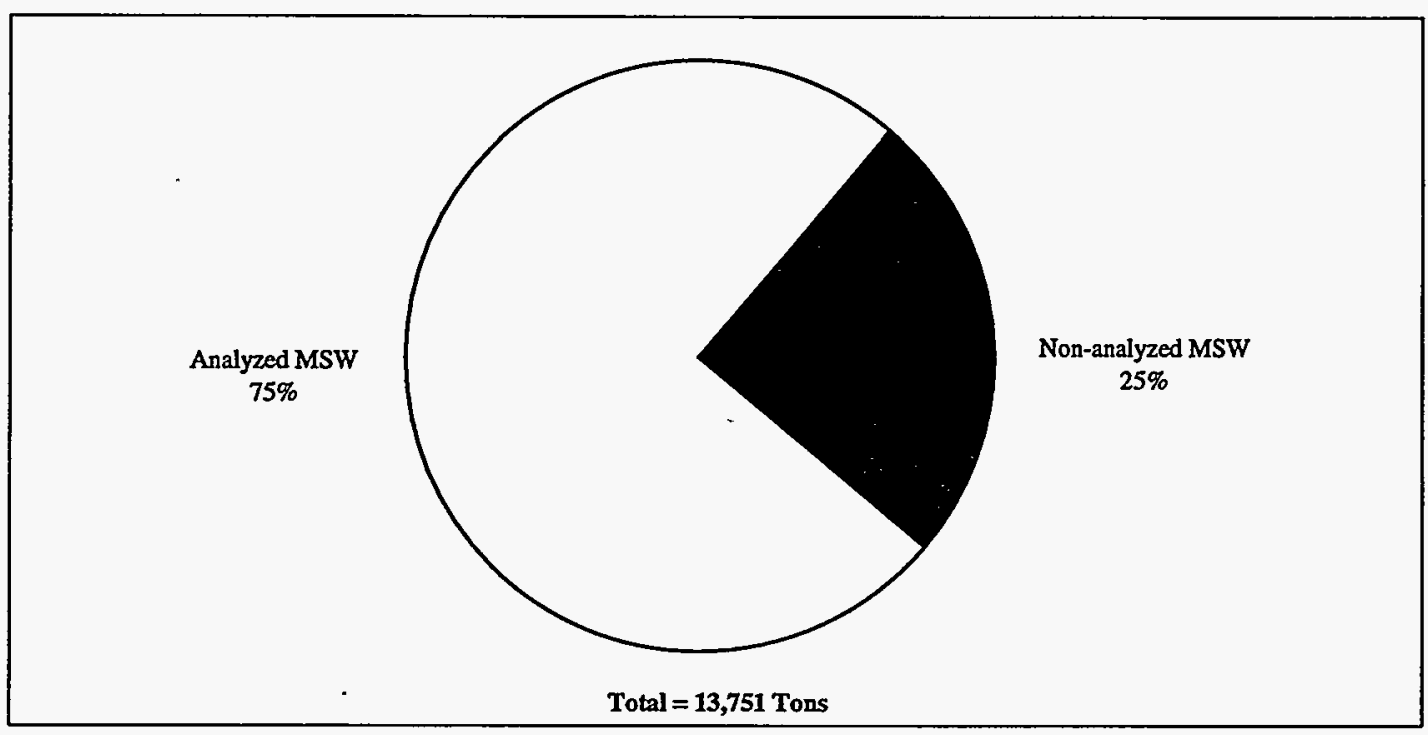

Figure 27. City of Sevierville Analyzed Waste by Type of Waste (Tons)

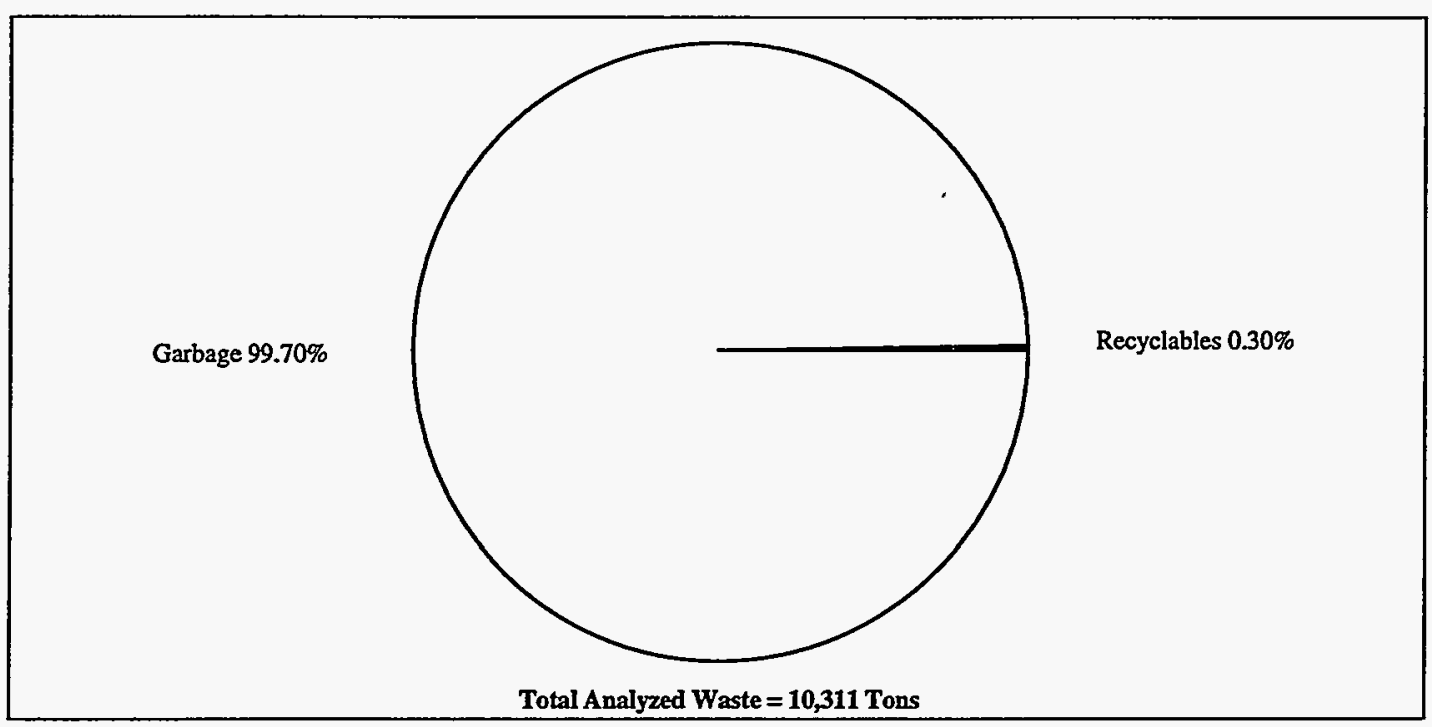


Figure 28. Ctty of Sevierville Net Costs of Managing MSW by Functional Area (FY 1993/94\$)

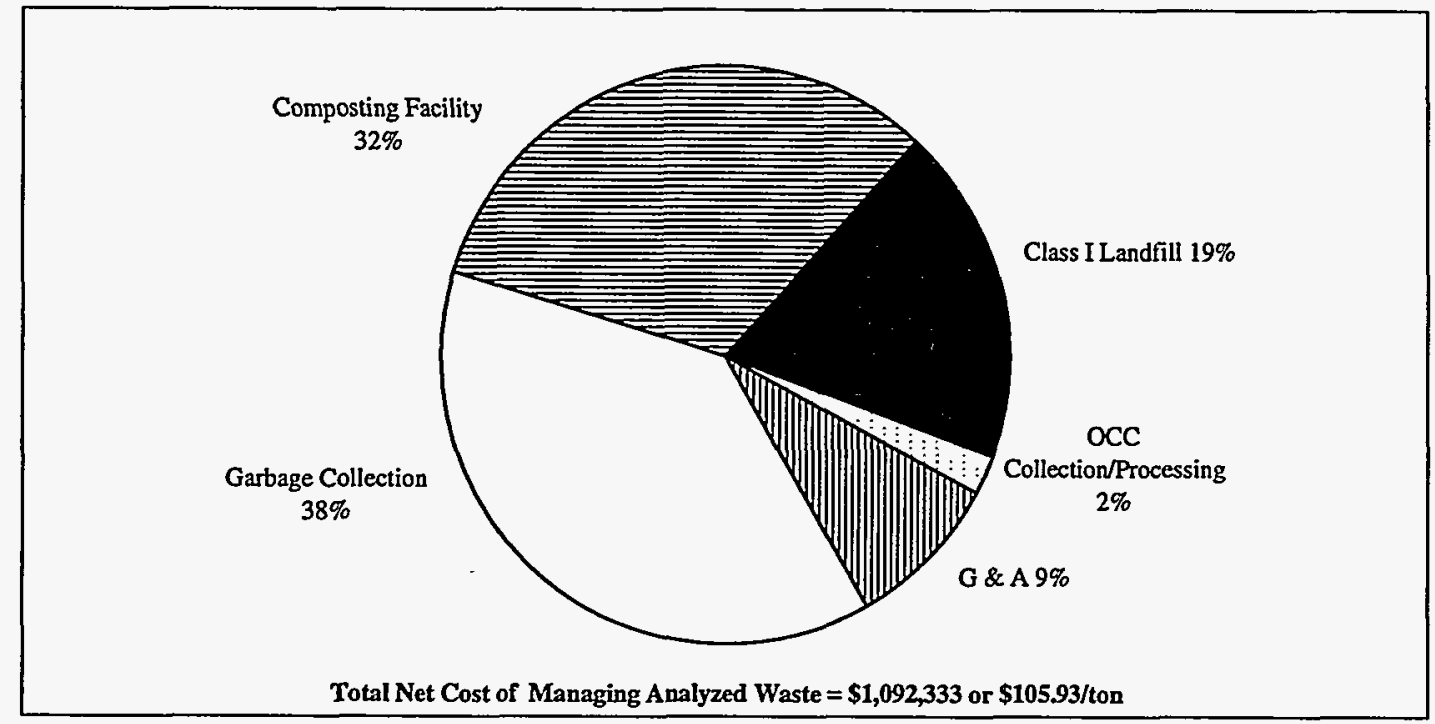

Figure 29. City of Sevlerville Allocation of Net Costs by Type of Waste (FY 1993/94\$)

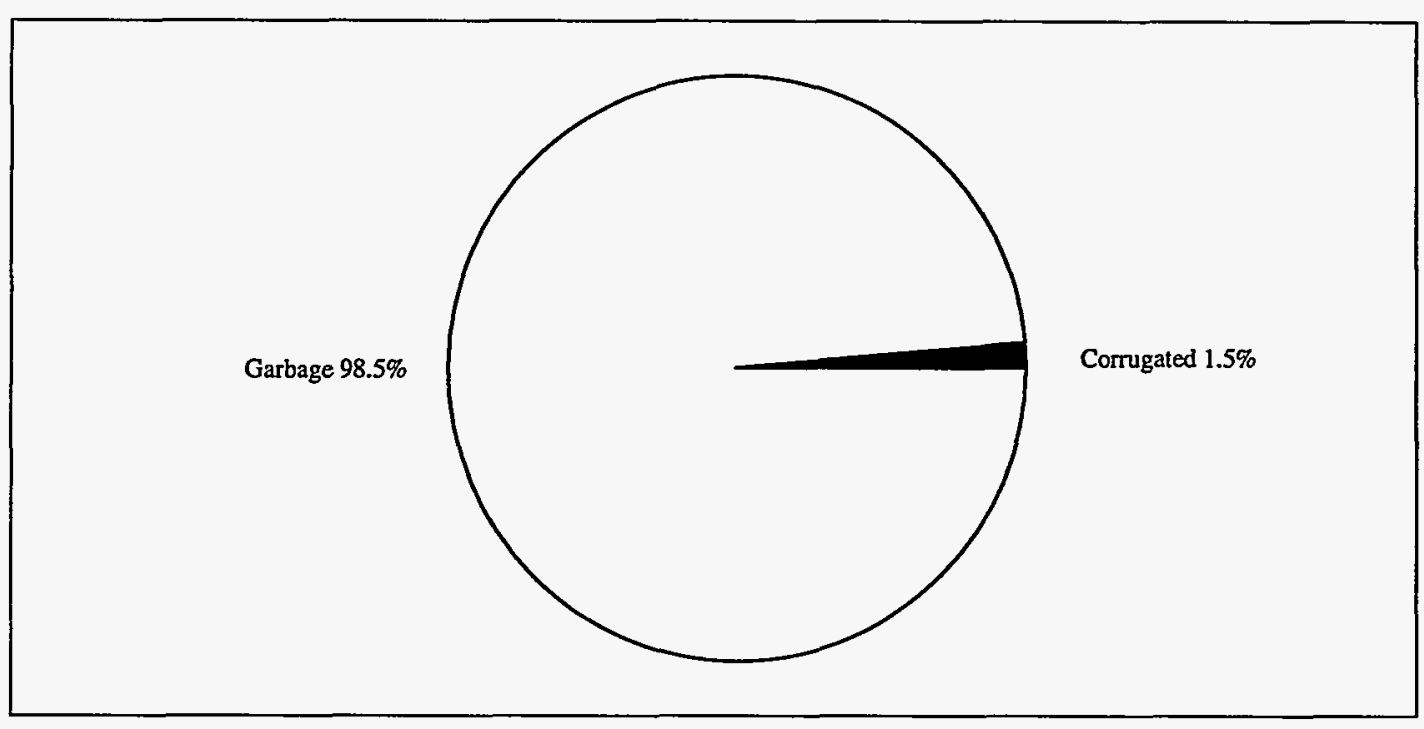


Figure 30. City of Sevierville Functional Allocation of New Costs by Type of Waste (FY 1993/94\$)

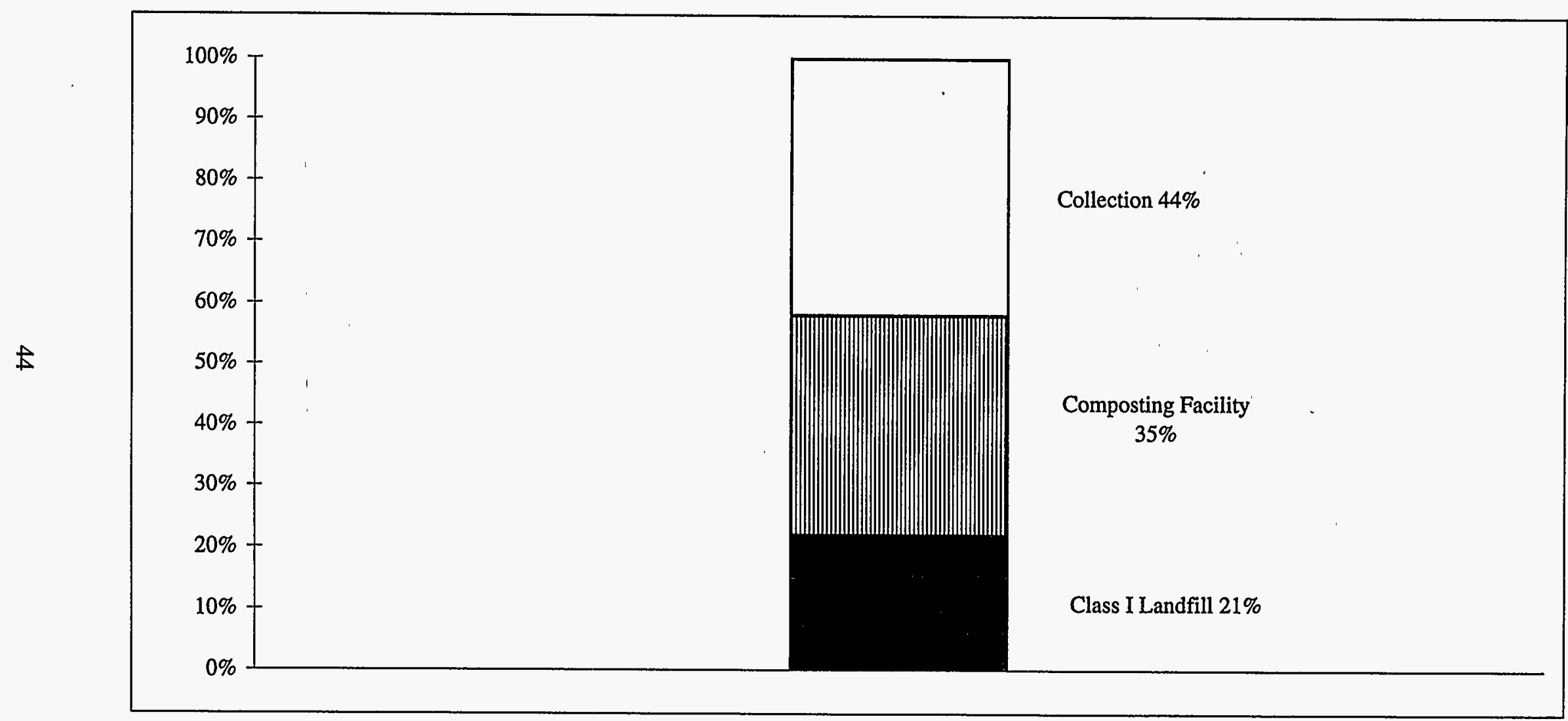




\section{Springfield, Massachusetts}

\section{Economy}

Historically, machinery, electrical equipment, and printing has served as economic mainstays, but there is also a significant amount of employment in finance, real estate, insurance and higher education.

\section{Institutional Arrangements}

The city owns and operates a yard waste composting operation, and owns a privately operated landfill used primarily for ash disposal. The city manages the collection, processing and disposal of MSW through the Department of Public Works. A regional WTE facility, privately owned and operated, serves ten surrounding communities, including Springfield. A privately operated regional material recovery facility (MRF), owned by the Commonwealth of Massachusetts, receives the city's recyclables at no cost since the Commonwealth pays all the capital and operating costs. The city's nonrecyclable bulky wastes are disposed at a privately owned and operated landfill located outside of the city.

\section{System Components}

The city's IMSWM system components include curbside garbage collection, and mandatory yard waste and recyclables collection. On-call bulky waste collection, office paper collection from city offices, and yard waste drop-off sites are also provided. HHW is collected on an annual collection day. The system components also include a MRF, a mass-burn WTE facility, and a white goods preparation and storage area. There is a source-separated yard waste compost facility, which uses a low-tech windrow approach, with a windrow tumer that rotates the material three times a week. Two landfills are included in the system components. One landfill, with a double liner system, accepts primarily ash and bypassed MSW from the WTE facility. The other landfill accepts non-recyclable bulky waste.

\section{Results}

Figures 31, 32, 33, 34 and 35 graphically present the results of the cost of Analyzed MSW management for the city of Springfield.

The average net cost to manage 59,900 tons of Analyzed MSW was $\$ 120$ per ton, in fiscal year 1993 dollars. The following table illustrates the average cost per ton for each category of waste analyzed.

Table 17. City of Springfield - Average Costs Per Ton (FY 1993 \$)

\begin{tabular}{lrcc}
\hline Category & Tonnage & Total Cost & Average Cost/Ton \\
\hline Garbage & 44,700 & $\$ 5.6$ million & $\$ 125$ \\
Recyclables & 7,580 & $\$ 1.01$ million & $\$ 136$ \\
Yard Waste & 6,810 & $\$ 0.38$ million & $\$ 57$ \\
Bulky Waste & 807 & $\$ 0.16$ million & $\$ 197$ \\
Total/Average & $\mathbf{5 9 , 9 0 0}$ & $\$ 7.17$ million & $\$ 120$ \\
\hline
\end{tabular}


The incremental costs (savings) are shown below:

Table 18. City of Springfield - Program Incremental Costs (Savings) and Diversion (FY 1993 \$)

\begin{tabular}{lccc|ccc}
\hline & $\begin{array}{c}\text { Tons } \\
\text { Managed }\end{array}$ & \multicolumn{2}{c}{$\begin{array}{c}\text { Program } \\
\text { Incremental Costs }\end{array}$} & \multicolumn{2}{c}{$\begin{array}{c}\text { Diversion from } \\
\text { Landfill }\end{array}$} \\
\cline { 3 - 7 } & & $\$$ & $\%$ & \multicolumn{2}{c}{ Tons } & $\%$ \\
\hline WTE Program & 45,677 & 322,500 & $4.7 \%$ & 30,546 & $50 \%$ \\
Curbside Recycling Program & 6,958 & 774,500 & $12.1 \%$ & 6,958 & $12 \%$ \\
Yard Waste Composting Program & 7,515 & 274,000 & $4.0 \%$ & 7,515 & $13 \%$ \\
Wastepaper Recycling Program & 22 & 1,496 & 0 & 22 & 0 \\
White Goods Recycling Program & 509 & $(41,229)$ & $(0.6)$ & 509 & $0.8 \%$ \\
\hline
\end{tabular}

The primary forms of energy used within Springfield's IMSWM system are transportation fuel for collection, haul to market, and facility vehicles; number 2 fuel oil, and electricity. The information was collected from the city and operators of the MRF, RRF, etc. Some engineering estimates were made to supplement the data received. The following table summarizes the energy consumption for collection of garbage, bulky waste, office paper, and recyclables.

Figure 19. City of Springfield - Energy Consumed to Collect Garbage, Bulky Waste, Office Paper, and Recyclables in Springfield (FY 1993 Equivalent Diesel Gallons Per Ton)

\begin{tabular}{lccccc}
\hline Variables & Garbage & $\begin{array}{l}\text { Bulky } \\
\text { Waste }\end{array}$ & $\begin{array}{l}\text { Yard } \\
\text { Waste }\end{array}$ & $\begin{array}{l}\text { Office } \\
\text { Paper }\end{array}$ & Recyclables \\
\hline $\begin{array}{l}\text { Tons Collected } \\
\begin{array}{l}\text { Diesel Fuel Consumed } \\
\text { (gallons) }\end{array}\end{array}$ & 44,707 & 1,316 & 6,814 & 22 & 7,048 \\
$\begin{array}{l}\text { Millions of Btus } \\
\text { Gallons/Ton }\end{array}$ & 46,598 & 3,617 & 3,601 & 127 & 14,017 \\
\hline
\end{tabular}

Note: Conversion to millions of Btus assumes 146,390 Btus per gallon

Source: City of Springfield - DPW, "Determinations of Fiscal Year 1993 Total Costs for Various Solid Waste Programs," Computer Printout, August 20, 1993. 
Figure 31. City of Springfield Total Waste (Tons)

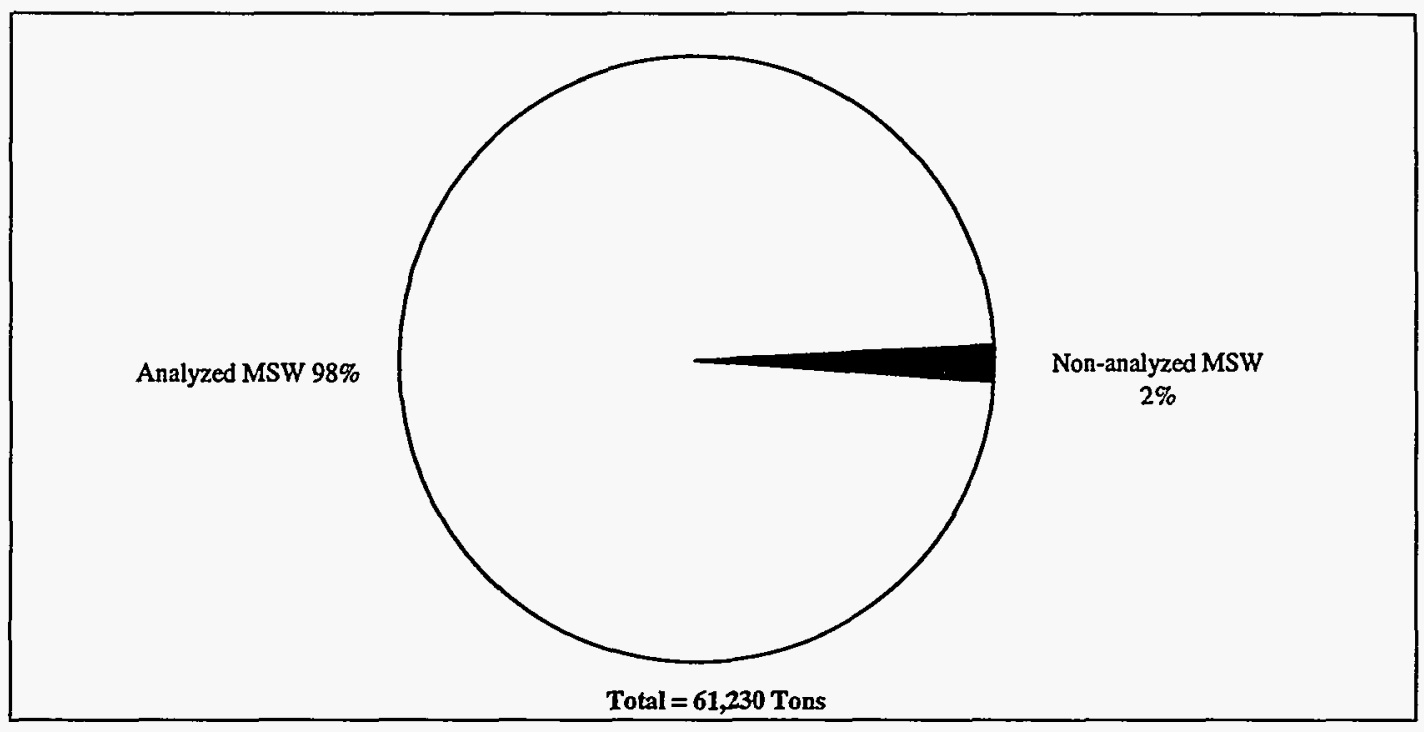

Figure 32. City of Springfield Analyzed Waste by Type of Waste (Tons)

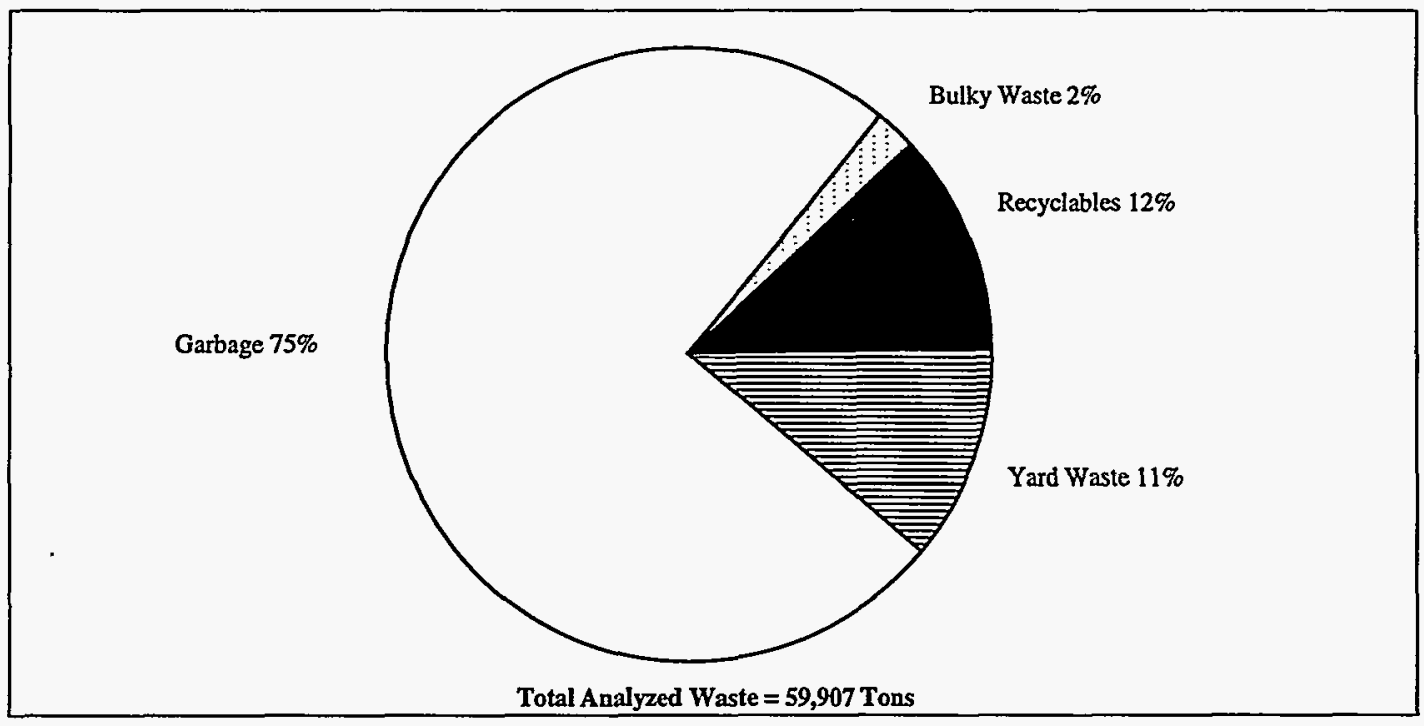


Figure 33. City of Springfield Net Costs of Managing Analyzed MSW by Functional Area (FY 1993\$)

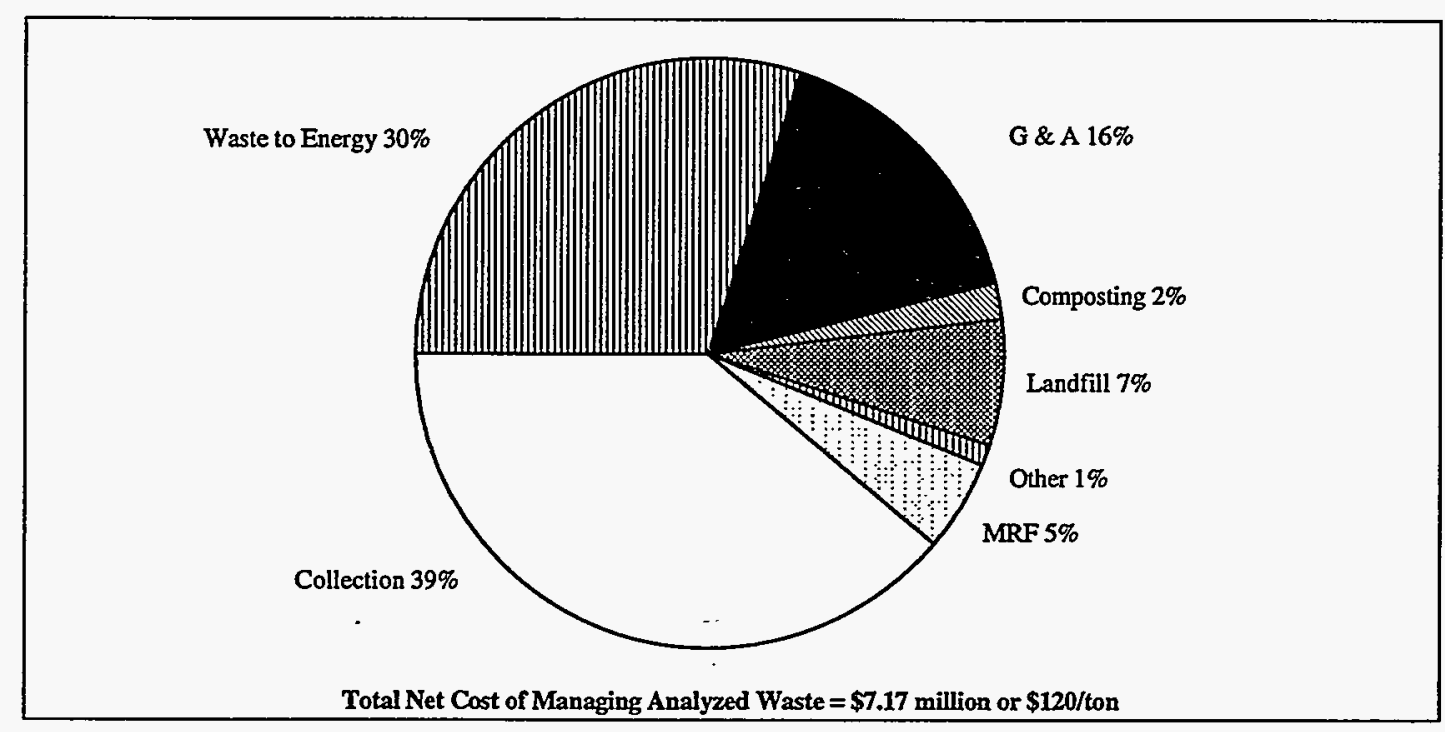

Figure 34. City of Springfield Allocation of Net Costs by Type of Waste (FY 1993\$)

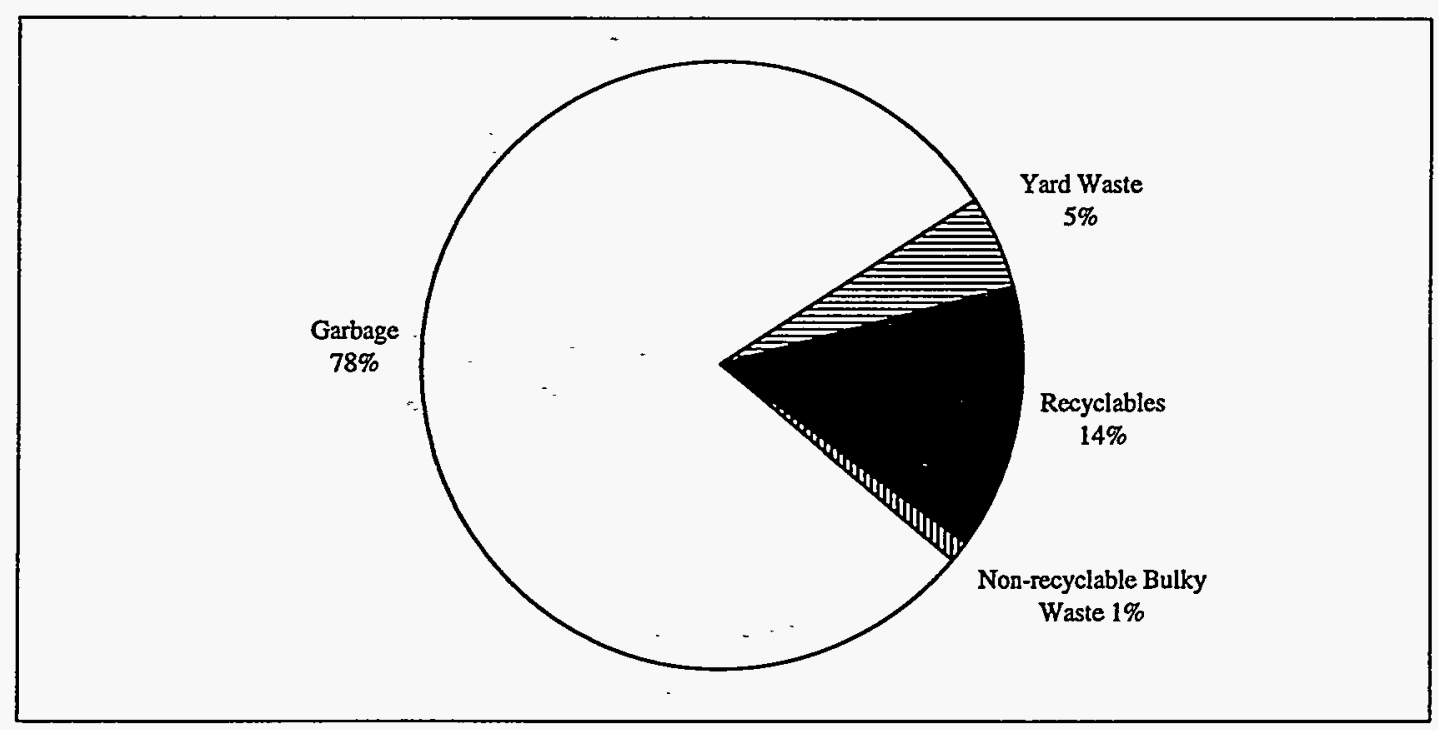


Figure 35. City of Springfield Functional Allocation of Net Costs by Type of Waste (FY 1993\$)

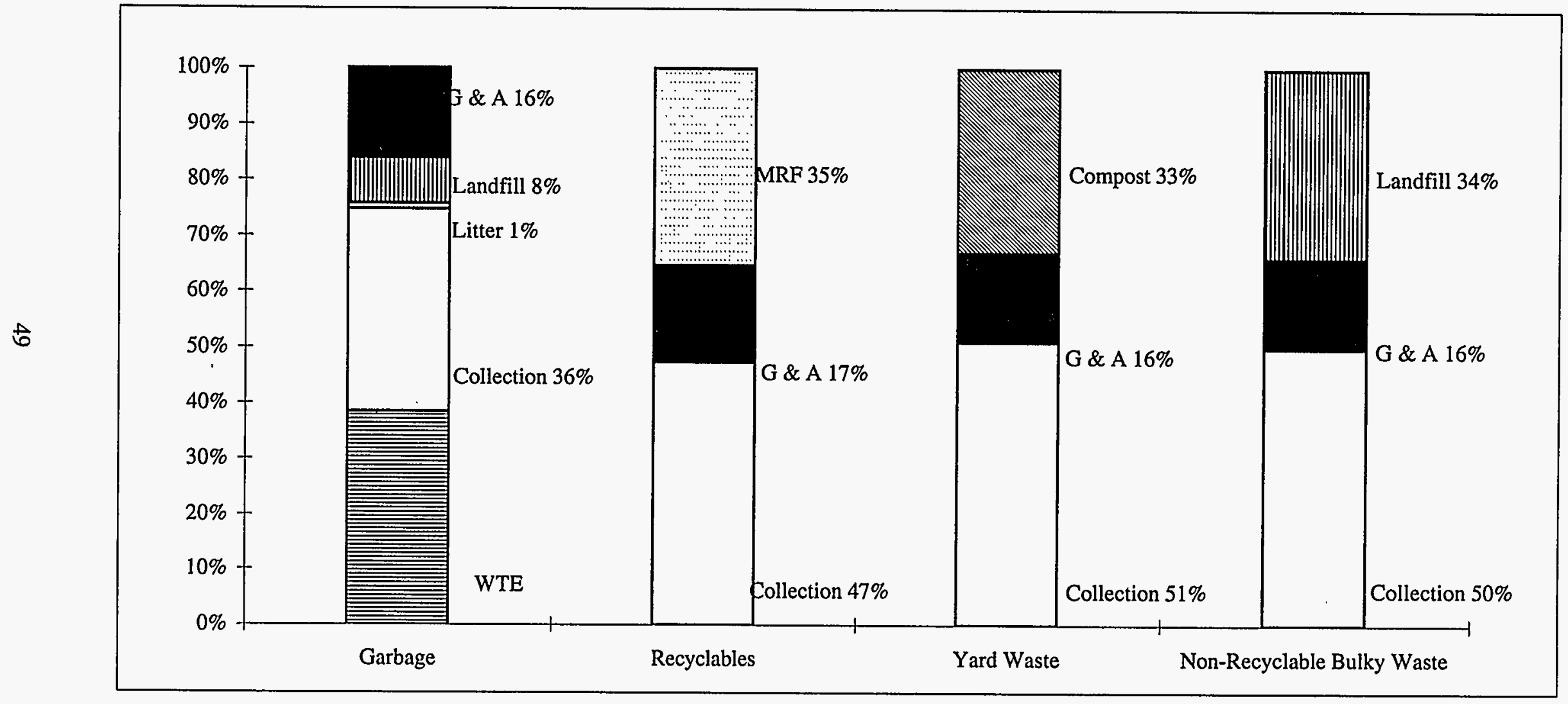




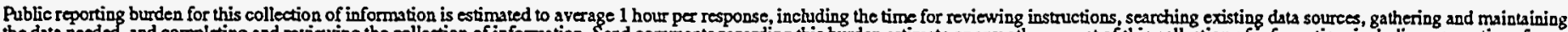

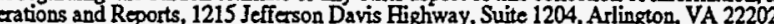
Maduagement and Budget, Paperwork Reduction Project (0704-0188), Washington, DC 20503.

\begin{tabular}{|l|l|l|}
\hline $\begin{array}{l}\text { 1.AGENCY USE ONLY (Leave } \\
\text { blank) }\end{array}$ & $\begin{array}{c}\text { 2. REFORT DATE } \\
\text { November } 1995\end{array}$ & $\begin{array}{c}\text { 3. REPORT TYPE AND DATES COVERED } \\
\text { Final Subcontract Report }\end{array}$ \\
\hline
\end{tabular}

4. TITLE AND SUBTITLE

Integrated Municipal Solid Waste Management: Six Case Studies of System Cost and Energy

Use. A Summary Report

5. FUNDING NUMBERS

6. AUTHOR(S)

(C) AR-2-12242

(TA) WM41.1010

\section{PERFORMING ORGANIZATION NAME(S) AND ADDRESS(ES)}

SWANA

1100 Wayne Ave.

Silver Spring, MD 20910

9. SPONSORING/MONITORING AGENCY NAME(S) AND ADDRESS(ES)

National Renewable Energy Laboratory

1617 Cole Blvd.

Golden, CO 80401
8. PERFORMING ORGANIZATION REPORT NUMBER

DE96000482

10. SPONSORINGMONITORING AGENCY REPORT NUMBER

NREL/TP-430-20471

\section{SUPPLEMENTARY NOTES}

NREL technical monitor: Philip Shepherd, (303) 275-2929

12a. DISTRIBUTIONAVAILABILITY STATEMENT

National Technical Information Service

U.S. Department of Commerce

5285 Port Royal Road

Springfield, VA 22161 12b. DISTRIBUTION CODE

UC-1414

13. ABSTRACT (Maximum 200 words)

Report documents an evaluation of the environmental, economic, and energy impacts of integrated municipal solid waste management systems in six cities: Minneapolis, MN; Springfield, MA; Seattle, WA; Scottsdale, AZ; Palm Beach County, CA; and Sevierville, TN. The primary objective of these case studies was to develop and present consistent cost, resource use (especially energy), and environmental regulatory information on each operating IMSWM system. The process is defined as using two or more alternative waste management techniques. Detailed reports on each system are available.

14. SUBJECT TERMS

energy conservation, material recovery facilities, municipal solid waste management, water quality
18. SECURITY CLASSIFICATION OF THIS PAGE
19. SECURITY CLASSIFICATION OF ABSTRACT
15. NUMBER OF PAGES 300

16. PRICE CODE

20. LIMITATION OF ABSTRACT

Standard Form 298 (Rev. 2-89) Prescribed by ANSI Std. Z30-18 